\title{
Corporate Lobbying and Firm Performance
}

\author{
Hui Chen ${ }^{*}$ \\ Department of Business Administration \\ University of Zurich \\ hui.chen@business.uzh.ch \\ David Parsley $^{* *}$ \\ Owen Graduate School of Management \\ Vanderbilt University \\ david.parsley@vanderbilt.edu \\ Ya-Wen Yang \\ School of Business \\ Wake Forest University \\ yangyw@,wfu.edu
}

October 2014

\begin{abstract}
Corporate lobbying activities are designed to influence legislators, regulators, and courts, presumably to encourage favorable policies and/or outcomes. In dollar terms, corporate lobbying expenditures are typically one or even two orders of magnitude larger than spending by Political Action Committees (PAC), and unlike PAC donations, lobbying amounts are direct corporate expenditures. We use data made available by the Lobbying Disclosure Act of 1995, to examine this more pervasive form of corporate political activity. We find that on average, lobbying is positively related to accounting and market measures of financial performance. These results are robust across a number of empirical specifications. We also report market performance evidence using a portfolio approach. We find that portfolios of firms with the highest lobbying intensities significantly outperform their benchmarks in the three years following portfolio formation.
\end{abstract}

JEL Classification code: G31, G38, D22

Keyword: Corporate Lobbying, accounting performance, market returns, portfolio; Citizen's United

${ }^{*}$ Corresponding author: Hui Chen, Department of Business Administration, University of Zurich, Plattenstrasse 14, Zurich, 8032 Switzerland, Phone: + 41446345178

${ }^{* *}$ Parsley acknowledges financial support from The Financial Markets Research Center at Vanderbilt University.

We thank Paul Chaney, Mara Faccio, Alexei Ovtchinnikov, Steve Rock, Jacob Sagi, Phil Shane, Shang-Jin Wei, and seminar participants at University of Colorado, Colorado State University, Peking University, Melbourne Business School, the University of New South Wales, and Vanderbilt University for comments. We also thank the Center for Responsive Politics (CRP) for providing the data and many discussions concerning the methodology, and Christoph Schenzler for assistance in matching the lobbying data to the financial information provided in the CRSP and Compustat databases. 


\section{Introduction}

The impact of corporate political activity in the United States is a hotly debated issue, especially since the 2010 Supreme Court Citizens United ruling, which relaxed constraints on corporate (and other groups') spending on elections. Early studies of corporate political activity (e.g., Snyder, 1992) focused on whether political contributions affect legislative voting outcomes. Snyder concludes that "despite years of research by political scientists and economists, the extent to which money actually buys political influence on a regular basis remains a mystery." More recently, studies have considered outcomes from the perspective of the firm, rather than political outcomes, in areas such as tax rates (Richter, Samphantharak, and Timmons, 2009), regulatory oversight (Bonardi, Holburn, and Vanden Bergh, 2006; Lux, Crook, and Woehr, 2011), earmarks (De Figuerido and Silverman, 2006), tariffs (Mayda, Ludema, Mishra, 2010), and government contracts (Goldman, So, and Rocholl, 2012). ${ }^{1}$

The goal of this study is to extend the analysis to overall corporate financial performance, and to focus the analysis on corporate spending (i.e., lobbying activities) as opposed to a more typical focus on contributions by Political Action Committees (PACs). Specifically, we attempt to estimate causal effects of corporate political activity on firms' subsequent financial performance. By studying all firms for which we can get financial data, including those that are not politically active, we take advantage of the data's panel structure, thereby allowing us to control for all time invariant firm-specific omitted variables when comparing firms that lobby with those which do not. Nichols (2007) and Angrist and Pischke (2009) advocate this as one way to address the bias due to unobserved confounders, common in studies relying on observational data. As a second identification strategy we use a matching technique to study the stock market performance of portfolios of lobbying and matched firms.

As noted, most studies of corporate political activity examine spending by corporate affiliated Political Action Committees. Miylo, Primo, and Groseclose (2000) explain the “inordinate attention to PAC contributions" by noting that "data on contributions are readily

\footnotetext{
${ }^{1}$ Other recent studies of corporate political activity include: Agrawal and Knoeber (2001), Alexander, Scholz, and Mazza (2009), Ansolabehere, Snyder, and Ueda (2004), Cooper, Gulen, and Ovtchinnikov (2010), de Figueiredo and Tiller (2001), Fan, Wong, and Zhang (2007), Fisman (2001), Goldman, Rocholl, and So (2009), Hill, Kelly, and Van Ness (2013), Hillman, Keim, and Schuler (2004), Igan, Mishra, and Tressel (2009), Kim (2008), and Yu and Yu (2011).
} 
available and PACs are easily linked to their corporate or industry sponsors". Brasher and Lowery (2006) caution that such research is too "narrow", and suggest that empirical findings concerning PAC behavior may not be generalizable; their study then argues that corporate lobbying is the more appropriate focus. The key distinction, according to Ansolabehere, de Figueiredo, and Snyder (2003) is that since PAC dollars are actually contributions by individuals, and not corporations, PAC spending should not even be considered 'corporate'. In contrast, lobbying is a corporate expense - presumably made with a view toward the firm's bottom line. Given these critiques, this study focuses instead on the impact of corporate lobbying on subsequent corporate financial performance.

Additional motivation for this study is provided by recent research into the financial implications of corporate connections with politicians. Generally, these studies conclude that connected firms receive specific benefits from political connections, and importantly, that the value of these connections is priced in financial markets. ${ }^{2}$ Recent studies find, for example, that political connections lead to better access to finance, and/or lower taxation, government bailouts, higher market returns, more government contracts, and greater market share, e.g., Claessens, Feijen, and Laeven (2008), Faccio (2006), Faccio, Masulis, and McConnell (2006), Leuz and Oberholzer-Gee (2006), and Goldman, So, and Rocholl (2012).

Econometrically, we rely on the assumption that the impact of time-dependent omitted variables is minimal. This suggests that given the severity of the global financial crisis, the likelihood that firms made unique, one-off spending decisions, cannot be discounted. For this reason we mainly focus on lobbying during the pre-crisis years $1998-2005 .{ }^{3}$ We hand match lobbying data to financial data from Compustat, and to stock market returns and security pricing data from CRSP, for as many firms as have data available. We begin with the approach taken by researchers studying the value of corporate Research and Development (R\&D) expenditures (e.g., Sougiannis, 1994; Lev and Sougiannis, 1996). We examine three accounting measures of performance released in firms' financial statements: income before extraordinary items, net income, and operating cash flows. The evidence we present points to

\footnotetext{
${ }^{2}$ These studies do not conclude that firms with political connections necessarily enjoy superior financial performance, e.g., Fan, Wong, and Zhang (2007).

${ }^{3}$ Following the suggestion of a referee, we do examine one important out-of-sample event. Specifically, in Section 3.c we ask whether lobbying activity or market performance of firms engaged in lobbying activities changed relative to other firms in the time period following the U.S. Supreme Court Citizens United decision.
} 
a robust, positive relationship between corporate lobbying expenditures and firm financial performance, though the results are weaker when focusing on cash flows from operations. In robustness exercises, we attempt to provide a more nuanced view by considering nonlinearity in the relationship, and principal agent interpretations via sub-sample regressions (e.g., limiting to large lobbying spenders only, and to firms with weak investor protection only).

In Section 3b, we abandon the panel approach and adopt a portfolio approach focusing on market returns. Specifically we compare excess returns of portfolios of matched lobbying and non-lobbying firms. We follow the portfolio approach used by Chan, Lakonishok, and Sougiannis (2001) who study the stock market valuation of R\&D expenditures; hence both of our empirical approaches derive from studies of R\&D. One important benefit of this portfoliobased approach is that it mitigates concerns about reverse causality and endogeneity, since the focus of the analysis is on future (i.e., one-, two-, and three-year ahead) excess market returns. Forecasts of future market performance at these horizons are highly unreliable, thus making endogeneity bias and reverse causality arguments less credible. We find that lobbying is positively correlated with future excess returns. In particular, firms with the highest lobbying intensities significantly outperform their benchmarks. Our results also suggest that most lobbying expenditures are not associated with abnormal returns, and that simply spending the most on lobbying does not necessarily lead to better stock market returns. However, since our (indeed all) matching relies on observables we caution that the results are conditional on our matching procedures.

The rest of the paper is organized as follows. Section 2 describes the data and how we arrive at our final sample. Section 3 develops our research design and presents the results of the analysis. Section 4 concludes.

\section{Data}

The Lobbying Disclosure Act of 1995 established the registration and reporting requirements for those who seek to affect U.S. government policies or the implementation of Federal programs. Registrants must file semi-annual reports (within 30 days of the end of the 
semi-annual period) detailing the issue they lobby for and the amount spent. ${ }^{4}$ The Center for Responsive Politics (CRP) data includes lobbying, PAC contributions, and soft-money as distinct categories. It is compiled using the semi-annual lobbying disclosure reports filed with the Secretary of the Senate's Office of Public Records and is available by calendar year since 1998.

The CRP sums the mid-year and year-end total amounts of expenses reported by a registrant to arrive at annual figures for each firm. Adjustments are made if there are any subsequent amendment reports correcting the originally reported amount in either the midyear or year-end filings. Lobbying can be done in-house, and/or via a contractual arrangement with external lobbyists to lobby on a firm's behalf. These external lobbyists must report for whom they lobby. The CRP uses the amount reported by the organization (including both inhouse lobbying and external lobbyist filings) as the total lobbying expenditure for the period. Thus, even if an organization does not file for lobbying itself (e.g., because it has no in-house lobbying), the CRP sums all of the organization's contracted lobbying expenditures reported by its external lobbyists. Finally, when a parent firm and its subsidiary both file for lobbying, the CRP attributes all lobbying expenses to the parent firm. ${ }^{5}$

The CRP lobbying data include spending by publicly traded firms, privately held firms, trade associations, ideological organizations, and non-profit organizations. We merged the data with Compustat to extract only public firms. Since CRP does not use company identifiers (e.g., CUSIP, PERMNO, etc.), we manually verified the names of the public firms to ensure the matching between Compustat and CRP lobbying data.

Table I compares the three categories of corporate political involvement for firms in Compustat that lobbied during the sample period. The relative magnitudes of lobbying, PAC contributions, and soft money donations are reported. Note that both PAC and soft money are reported by election cycle rather than calendar year. Perhaps surprising to many, lobbying is relatively uncommon, despite its being the predominant form of corporate political activity. At the beginning of our sample only $6.5 \%$ of the firms in Compustat lobbied, though that

\footnotetext{
${ }^{4}$ Typically, issues are very general, e.g., "Lobby for business and workforce development programs and appropriations". The CRP provides a considerable service by sifting, matching, and cleaning the raw lobbying disclosure data. To access the Senate lobby reports and registrations database, go to http://sopr.senate.gov. ${ }^{5}$ See http://www.opensecrets.org/lobbyists/methodology.asp for more details about the CRP's methodology.
} 
number has been growing over time, reaching $11.8 \%$ of Compustat firms by the end of our sample. Nonetheless, media investigations often portray corporate lobbying activities in scandalous overtones. ${ }^{6}$ Also, it is clear that lobbying accounts for the lion's share (in both dollar amounts and in the number of firms involved) among all types of corporate political expenditures. ${ }^{7}$ If we compare the average firm's political spending across the three categories (by aggregating lobbying expenses per year into amounts per election cycle to match the reported PAC and soft money) in the 1998 election cycle, for instance, we see that lobbying is around 22 times greater than PAC contributions, and around 20 times greater than soft-money contributions. $^{8}$ All three types of spending increase across the sample, though soft money is relatively constant in the final two election cycles of its existence (i.e., 2000 and 2002).

Figures $1 \mathrm{a}$ and $1 \mathrm{~b}$ present the aggregate, and average, annual lobbying expenditures of sample firms graphically. The figures confirm that much of the growth in lobbying expenditures is due to additional firms, since the per-firm average has been roughly constant at about $\$ 540,000$, with the exception of the last two years of the sample where it increased by about $\$ 40,000$. Table II lists the top twenty contributors in 2005. Indeed, these firms are often large and the amounts they spend on lobbying are impressive, with General Electric spending close to $\$ 19$ million in 2005 alone. ${ }^{9}$ These aspects of corporate lobbying (i.e., few, and generally larger, firms lobbying persistently) suggest caution in overstating estimated impacts for firms not already lobbying.

In Table III, we look across industry group and year. Firms in manufacturing (two-

\footnotetext{
${ }^{6}$ News accounts citing lobbying financial benefits include The Washington Post (2006) reporting that 60 companies (including Pfizer, Hewlett Packard and Altria) collectively spent approximately \$1.6 million dollars lobbying for a special low tax rate worth $\$ 100$ billion dollars, which would apply to the firms' earnings from foreign operations. The same article quoted the case of Carmen Group Inc., a lobbying services firm claiming to deliver a 100 to 1 (dollar) benefit-to-cost ratio for its clients. Similarly, Fortune (2006) estimated similarly large rates of return on political investment: 163,536\% for Lockheed Martin, which spent \$55 million in lobbying since 1999 and won roughly $\$ 90$ billion in defense contracts; and 142,000\% for Boeing, which spent \$57 million and got $\$ 81$ billion in contracts.

${ }^{7}$ If we restrict the sample to only those firms engaged in all three forms of political involvement, the number of firms falls below 200 (or roughly one-third of the full sample), and the resulting sample spends on average nearly three times more on lobbying than in the full sample. In our regression analysis we do not restrict the sample to just these firms.

${ }^{8}$ Total lobbying spending of our sample firms in the 1998 election cycle is $\$ 789,391,490$ $(=704 * \$ 554,628+765 * 521,482)$ and the amount of PAC contributions is $\$ 36,385,753(=430 * \$ 84,618)$.

${ }^{9}$ In their study on the determinants of lobbying, Kerr, Lincoln, and Mishra (2011) note also that lobbying is strongly related to firm size and is highly persistent. These authors conclude that the existence of substantial entry costs can explain why so few firms lobby, its relation to firm size, as well as lobbying's persistence.
} 
digit SIC=20-39), transportation and utilities (two-digit SIC=40-49), and finance, insurance and real estate industries (two-digit $\mathrm{SIC}=60-69$ ) are more active in lobbying activities than are other firms, evident by the average lobbying spending. The public administration industry (two-digit $\mathrm{SIC}=90-99$ ) has the highest average lobby spending among all the industry groups, however, there are relatively few firms in public administration involved in lobbying in most years, and most of these firms are conglomerates. These differences suggest to us the importance of controlling for industry effects in our analysis.

To ensure that the lobbying data and financial data correspond to the same time period, we focus our analysis on firms with fiscal year ending December 31. Our sample of lobbying firms is reduced to just below 7000 firms due to the elimination of firms with non-calendar fiscal year end.

Panels A and B of Table IV report descriptive statistics for the various measures of accounting performance, lobbying, and other independent variables used in our analysis. Panel A focuses on firms that lobby, and Panel B reports data for all firms in Compustat. The most obvious conclusion from comparing Panel A with Panel B is that firms with non-zero lobbying spending are, on average, substantially larger.

\section{Research Design and Results}

The theoretical basis for this study originates in research into the political economy of business and regulation such as Stigler (1971). In Stigler's view the State, through its power to tax, subsidize, and regulate, can selectively help or hurt particular firms or industries. He discusses several specific forms of government influence, including: subsidies and earmarks (e.g., veterans, airlines, and universities); control over entry or rivals (e.g., commercial airline authority, and, entry into banking); and import tariffs. According to Stigler, lobbying can generate positive returns for firms by any one (or a combination) of several means: securing direct subsidies or lower taxes, getting government contracts, limiting competition, or permitting entry into previously protected markets. In addition to Stigler (1971), there are other explanations for the role of lobbying. For example, Grossman and Helpman $(1994,2001)$ view lobbying as a means for interest groups to communicate with policy-makers and inform them with local knowledge. Gordon and Hafer (2005) propose that lobbying is a costly signal sent by interest groups, and conveys a credible threat to the regulators of the interest groups' 
willingness to fight. Both alternative theories imply an empirical prediction of a positive association between lobbying and financial performance.

Empirically, our primary difficulty in estimating causal effects using non-experimental observational data is self-selection, which arises from endogeneity. As stressed by Nichols (2007) and Angrist and Pischke (2009), such data present researchers with serious challenges since the treatment variables (e.g., lobbying) are not randomly assigned. That is, some firms lobby while others abstain - based on circumstances peculiar to the firm itself. For example, firms (but not the econometrician) may have reason to believe (e.g., through a personal connection) that lobbying will be successful (or unsuccessful) in say, yielding a government contract. Hence, an inference that an OLS estimated coefficient reflects the impact of lobbying on any firm's financial performance may be misleading. Absent an instrumental variable that affects lobbying but not firm financial performance, or a suitable assignment variable for use in a regression discontinuity design, we focus on panel and matching methods to control for omitted variable bias. We also provide some sensitivity analyses in an attempt to mitigate concerns that the results are dependent on particular functional forms or samples.

In our context, the key benefit to using panel methods is in using firm $i$ as its own control group. Hence, the identification requirement here is that omitted confounding variables are time invariant. This is an important assumption but we believe it is reasonable in our context for several reasons. First, firms tend to lobby for specific pending legislation and court cases which from the firm's perspective arise more or less randomly. ${ }^{10}$ Some examples from recent studies seem to corroborate this notion. First, Alexander, Scholz, and Mazza (2009) find that the tax holiday created by the American Jobs Creation Act of 2004 led to a surge in lobbying and an estimated one-time 22,000\% return. Richter, Samphantharak, and Timmons (2009) report that Bartlett and Steele (1988) identify “650 special tax emptions for specific firms or individuals" within the 1986 Tax Reform Act alone. More recent examples include the lobbying subsequent to the 2009 Stimulus Act (e.g., Igan, Mishra, and Tressel 2009; Adelino and Dinc 2013). These more or less random opportunities lend some support to our fixed effects estimation strategy. However, clearly as the scope of firms' activity broadens,

\footnotetext{
${ }^{10}$ Here too, contributions (which tend to rise and fall with election cycles) differ from lobbying; making the fixed effects framework less plausible when studying contribution (e.g., PAC) data.
} 
there will be more 'random' opportunities; this makes our robustness exercises focusing on different sizes of firms even more salient.

As a further precaution against time dependent omitted confounding variables, we focus on the pre-crisis (2007-present) time period. Several recent papers have used the Global Financial Crisis (GFC), or the Citizens United case, as 'natural experiments' (e.g., Werner 2011, and Coates 2012). Given the magnitude and scope of the GFC it seems highly dubious to treat omitted confounding variables invariant over this time period. That said, we recognize that even within our sample period, our results will still be biased if lobbying expenditures are correlated with time-varying omitted variables. We attempt to control for firm specific trends using lags of the dependent variable as described below.

\section{3.a Financial statement evidence}

To guide our empirical specifications, we draw from studies investigating the impact of R\&D expenditures on financial performance. Conceptually, lobbying is similar to R\&D in that each is undertaken voluntarily by (not all) individual firms, and yields uncertain future payoffs. Although lobbying (and R\&D) charges are incurred in a specific time period, the implications for performance may only be in subsequent years. In Table V we examine three standard measures of firm performance taken from firms' financial statements, and we present three econometric specifications for each measure since theory does not pin down the speed with which lobbying affects firm performance, for a total of nine regressions; $t$-statistics for coefficient estimates computed using heteroskedasticity consistent standard errors that are clustered at the firm level (Moulton 1986) are reported in parentheses. ${ }^{11}$ Our three econometric specifications parallel those developed in Sougiannis (1994), Amir and Lev (1996), and Lev and Sougiannis (1996).

One critique that is immediately apparent concerns the direction of causality, i.e., does lobbying influence financial performance or the reverse? Hence in Appendix Table 2 we present the reverse regressions for each of our three measures of financial performance. Consistent with the theory and prior research, these specifications point toward lobbying

\footnotetext{
${ }^{11}$ Table V includes all firms for which we have data. Firms in Banking and Finance firms are often treated as a special category given that EBIT and cash flows have a slightly different meaning, and they tend to be more highly leveraged. Hence, regressions excluding firms in Banking and Finance are reported in Appendix 1. Since the results are quite similar, we include all firms in the remaining analysis, except where noted.
} 
impacting financial performance as the primary channel.

According to Table V, in columns (1) - (3), we present results for income before extraordinary items (IBEI) as the measure of financial performance. We choose income before extraordinary items instead of other earnings measures, such as income before interest, income tax, and depreciation and amortization, because lobbying activities may affect lobbying firms' effective tax rates and interest rates. In columns (4) - (6), we repeat the analysis using net income (NI), and in columns (7) - (9), we use cash from operations $(C F O)$, as alternative financial performance measures. The general specification we study is: ${ }^{12}$

Financial Performance $_{i t}=\beta L O B B Y_{i, t-1}+\alpha_{1} M B_{i, t}+\alpha_{2} A S S E T_{i, t}$

$$
\begin{aligned}
& +\sum_{k} \lambda_{\mathrm{k}} \text { Financial Performance }_{i, t-k}+\sum_{t} \delta_{\mathrm{t}} \text { Year }_{t} \\
& +\sum_{j} \gamma_{\mathrm{j}} \text { Industry }_{j}+\sum_{i} \varphi_{\mathrm{i}} \text { Firm }_{i}+\varepsilon_{i j t}
\end{aligned}
$$

Firms that do not lobby are assigned a zero for the value of their lobbying expenses. $A S S E T_{i, t}$ is the amount of total assets of firm $i$ at the beginning of year $t$; and Firm, Year, and Industry are firm, year, and Fama-French (Fama and French, 1997) industry dummies respectively. To control for firm specific drivers of financial performance, we include the firm's market-to-book ratio $(M B)$, size ( $A S S E T)$, and (up to) two previous year's financial performance to control for within-firm trends. Note that the fixed effects estimator is actually an estimation in deviations from means; hence the strategy punts on comparisons in levels while requiring the counterfactual trend behavior of lobbying and non-lobbying firms to be the same (see Angrist and Pischke, 2009).

Admittedly, this specification reflects a lot of ignorance regarding financial performance since dummy variables absorb a wealth of potentially interesting variation of interest to many researchers. However for our purposes, this 'generality' is incidental since we care only about the impact of lobbying on financial performance. Results from estimation of equation (1a) are given in Table V. Given that theory does not pin down specific lag lengths, we provide three specifications for each financial performance measure to mitigate potential problems from serial correlation, where we vary the number of lags of the dependent

\footnotetext{
${ }^{12}$ Scaling $\angle O B B Y$ by assets or sales produce qualitatively similar results. Similarly, scaling both $L O B B Y$ and the dependent variables by assets or by sales produces qualitatively similar results.
} 
variable and of lobbying across the specifications.

In additional (though not reported) robustness specifications we included three lags of the dependent variable. These produce similar results, though with a smaller sample size. Similarly, to mitigate the impact of outliers, we repeated these regressions excluding observations in the top and bottom 1 percent of the dependent variable. Again, the results are substantially unaffected. Finally, we re-estimated the models allowing for cross-sectional (as well as heteroskedasticity and within firm autocorrelation) using the Driscoll-Kraay estimator. Our results again were substantially unaffected.

In Table $\mathrm{V}$, focusing on $I B E I$, in columns $1-3$, we see that lobbying is positively related to financial performance. The amount of variation explained (as given by the $\mathrm{R}^{2}$ statistics) jumps substantially when we include a lagged dependent variable, but lobbying remains strongly statistically significant except for regressions focusing on cash from operations. This result is similar to that found by Hill, Kelly, and Van Ness (2013), which they interpret as indicating that lobbying (unlike corporate contributions) is driven by a profit maximization motive as opposed to agency motives, whereby the firm's managers lobby as a means of enhancing personal, as opposed to corporate, objectives. The coefficients on the lags of the dependent variable are generally statistically significant in each regression, implying persistence in these reported accounting measures of financial performance. The coefficient on the level of assets is statistically significant in all specifications suggesting that size effects are indeed important; however, the market-to-book ratio is never statistically significant.

The specifications given in Table V posit a relationship between this year's financial performance and last year's lobbying efforts; however, theory is not precise about the exact timing for the effects. Hence, we explore additional possible lag specifications in Appendix Tables 3-5. Specifically, we test for a contemporaneous link in Appendix Table 3, and then progressively add lags in Appendix Tables 4 and 5. Results from these specifications continue to indicate a statistically significant relationship between lobbying and firm financial performance; the contemporaneous relationship is slightly weaker, and often disappears when the specification includes lags of the dependent variable and lags of lobbying consistent with an impact that is not fully realized in the current period. Again, results focusing on cash from 
operations $(C F O)$ are weakest.

The magnitude of the coefficient estimates given in Table V or Appendix Tables 3-5 are large; on the surface they suggest that firms spending an additional 1 million dollars will see their financial performance jump by 50 to 80 times this amount. Even absent entry of new, non-lobbying firms, these returns should attract additional lobbying by firms already engaged in lobbying. Hence, we caution against concluding in favor of such outsized returns for several reasons. First, as suggested by Tables IV and V, lobbying is concentrated among large firms. Indeed, firms that lobby are roughly four times larger (by assets) than firms with zero lobbying expenditures. This may reflect the fact that large firms are more diversified, and more diversified firms are more likely impacted by more potential legislation, regulation, and court cases. Given the costs of maintaining relations with government officials over time, it may simply not be feasible for smaller firms to lobby (Olson, 1965). Moreover, as Adelino and Dinc (2013) note, these calculations ignore the opportunity cost of lobbying resources such as CEO time. Clearly there must be costs beyond simply the reported lobbying expenditures; recognizing these costs would lower the return to lobbying.

That said, lobbying may in fact yield windfalls to firms in a position to take advantage of the time-sensitive nature of a particular piece of legislation, e.g., an economic stimulus bill. That is, many firms simply may not have the necessary connections, lobbying capability, or scope of operations at the time stimulus bills are being discussed. In other words, lobbying may be 'lumpy'. To take an extreme example, spending lobbying dollars during periods when Congress is in recess might be pointless. Hence, the large coefficients only makes it appear that more lobbying will yield more returns. While we recognize these limitations, we follow the advice of Angrist and Pischke (2009) and check the robustness of our results using alternative identification assumptions and models. We consider an alternative specification of the basic panel estimation before turning to a portfolio estimation based on a matching strategy.

In Table VI we present results from a closely related specification focusing on changes in the dependent variable (financial performance). This specification is given as equation (1b): $\Delta$ Financial Performance $_{i t}=\beta \operatorname{LOBBY}_{i, t-1}+\alpha_{1} M B_{i, t}+\alpha_{2}$ ASSET $_{i, t}$ 


$$
\begin{aligned}
& +\sum_{k} \lambda_{\mathrm{k}} \text { A } \text { Financial Performance }_{i, t-k}+\sum_{t} \delta_{\mathrm{t}} \text { Year }_{t} \\
& +\sum_{j} \gamma_{\mathrm{j}} \text { Industry }_{j}+\sum_{i} \varphi_{\mathrm{i}} \text { Firm }_{i}+\varepsilon_{i j t},
\end{aligned}
$$

In equation (1b) " $\Delta$ " indicates the change from year $t-1$ to year $t . L O B B Y_{i, t-1}$ is the dollar amount of lobbying spending by firm $i$, in year $t-1$. In general, our results are robust across these several different specifications. Results presented in Table VI generally indicate a smaller effect of lobbying on the change in financial performance, and are cumulatively larger when the specification includes one lag of the dependent variable, but often become statistically weaker when the specification includes two lags of the dependent variable. The results support a positive relationship between lobbying and changes in financial performance (with caveats).

One drawback to the analysis so far is the assumed linear relationship. In particular, there may be threshold effects, whereby the relationship changes when lobbying expenditures become very large. To check for this sort of nonlinearity, we repeat these regressions focusing on the highest quartile of lobbying firms. The question is whether the positive association is being driven only by the firms that spend the most on lobbying. These results (Appendix Table 6) are quite similar to those presented in Table V. Hence, the positive association between lobbying and firm performance does not seem any more or less prevalent for the firms with the largest lobbying expenses.

There are several additional concerns that should be addressed before going further. These concerns make the interpretation of the positive regression coefficients difficult, in that the coefficient on lobbying may be proxying for something else. We discuss each of these in turn. First, lobbying could be correlated with an unobserved variable, e.g., government connections, which may be the real source of value to the firm. Should this be the case, the firm would lobby for issues or legislation the connected politician supports, in return for political favors. As a result, both the firm and the government official benefit from the lobbying activity, but the government connection is the true underlying cause. Unfortunately, we have no way to address this identification issue, since to do so we would need - at the least - to be able to identify a substantial subset of all firm/politician connections, which is beyond the scope of the present paper. However, since we cannot rule out additional political 
connections, the possibility remains that lobbying is picking up some unobserved source for the observed positive effect.

A second concern is that there could be an agency problem whereby managers having relatively high discretion tend to lobby most. ${ }^{13}$ In particular, the reported relationship might be masking the underlying relationship between managerial discretion and expected future firm performance. Specifically, managers with relatively high discretion over the decision to lobby may increase lobbying spending whenever they expect firm performance to be good. This alternative hypothesis implies that lobbying does not add value to the firm. Hence, we should observe a weaker relationship between lobbying and firm performance, or, even a reversal in the estimated coefficient for firms with weaker corporate governance characteristics.

To investigate this possibility we examine two widely used measures of corporate governance. The first measure, used by Gompers, Ishii, and Metrick (2003), attempts to measure shareholder rights across a large cross-section of U.S. firms. The second measure, produced by Bebchuk, Cohen, and Ferrel (2009), is designed to measure manager entrenchment comparatively over a similarly broad set of U.S. corporations. Bebchuk et al. (2009) propose their "E-index" measure as an improvement over that proposed by Gompers et al. (2003). Both measures use underlying data from the Investor Responsibility Research Center. As a start, we first check the simple correlation of lobbying expenditures with these two measures. Empirically, the correlation coefficient is below 0.20 for our sample of firms and years. Hence, a priori, there seems little to suggest that our results depend on corporate governance characteristics. However, we still test the agency hypothesis directly by comparing the relations between lobbying and financial performance in the context of our regression framework.

Appendix Table 7 presents the results using the E-index measure developed in Bebchuk, Cohen, and Ferrel (2009). ${ }^{14}$ As in the case of firms with the largest lobbying expenditures, we repeat our regression analysis by focusing on firms with the weakest investor protection, i.e., those with an E-index in the top quartile. As can be seen from the

\footnotetext{
${ }^{13}$ For example, Ansolabehere et al. (2003) suggest managers could engage firms in political activities for their own personal political or ideological agenda.

${ }^{14}$ Their data is available at: http://www.law.harvard.edu/faculty/bebchuk/data.shtml
} 
table, the results are generally consistent with Table V across all nine specifications, though coefficients on lobbying rise among these firms suggesting a stronger impact of lobbying among poorly governed firms. All other coefficients are of similar magnitudes and significance levels. Thus the results suggest that lobbying undertaken by firms with weak investor protection benefit more than other firms - though there is nothing to suggest managers of such firms use their discretion inappropriately.

The natural question arises as to why the apparent gains have not been bid to zero via additional lobbying. First, recall that Kerr, Lincoln, and Mishra (2011) conclude that there are substantial entry costs to lobbying, i.e., firms must effectively sign on to a multiple-year contract, and their competitors in lobbying are large firms that have been lobbying (and relationship building) for some time. Unfortunately, these features of lobbying are very hard to test. Consistent with these features, Wirl (1994) concludes, based on a dynamic model of lobbying that in equilibrium, there will be an apparent under-investment in lobbying, due to potential retaliation. For example, an implicit threat by a dominant firm to raise lobbying expenditures to very high levels would discourage other firms from engaging in lobbying. Gordon and Hafer (2005) demonstrate that lobbying can be used as a credible threat by interest groups to regulators, showing that they are willing to fight against any potential unfavorable policy. This signal effect of lobbying also can explain why there are not more firms engaged in lobbying. Thus our results are consistent with the theoretical predictions of Wirl (1994), as well as Gordon and Hafer (2005). That said, we caution that our reported average effect may not apply equally to all firms out of sample - given the time, industry, and issue specific nature of lobbying.

To summarize, our results in Table VI are consistent with those presented in Table V, and point to a significant and positive association between lobby spending and future financial performance as measured by accounting data reported in firms' financial reports. In the next section we turn to market based evidence. That is, we ask whether this positive association is present in market-adjusted returns by comparing portfolios of lobbying and non-lobbying firms. This approach also lets us examine the cross-section of firms with non-zero lobbying expenses further by explicitly comparing them with portfolios of matched non-lobbying firms. 


\section{3.b Market return evidence}

Chan, Lakonishok, and Sougiannis (2001) investigate whether stock prices fully value firms' research and development $(\mathrm{R} \& \mathrm{D})$ activities. Many studies treat lobbying expenditures similar to R\&D since both are thought to yield a future (uncertain) return (i.e., an investment) and yet they are both expensed in the current period. Given that in an efficient market, stock prices reflect the value of firms' intangible assets, there should be no association between lobbying and future stock returns. However, unlike $R \& D$, access to data on what firms spend on lobbying has not generally been easily available, which would make valuation difficult. The problem goes both ways: i.e., not only might the market undervalue corporate lobbying activities due to ignorance, sensational news stories suggest valuations may be way too low for firms that lobby. To our knowledge, there has been no systematic study of the returns on shares of firms that lobby versus firms with no lobbying.

Thus, this section examines whether lobbying activity is associated with future stock returns and whether the stock market correctly anticipates the expected future benefits of lobbying spending. This section extends the analysis of previous sections which focused on reported returns in financial statements, to consider whether the stock market values lobbying activities. We follow Chan et al. (2001) and implement a characteristic-based matching investment strategy (also known as the buy-and-hold abnormal returns approach); specifically, we check whether lobbying is related to future stock returns and whether firms engaging in lobbying activities financially outperform those do not. For these tests we (again following Chan et al., 2001) construct two measures of lobbying intensity: (a) lobbying expenditures relative to assets, and (b) lobbying expenditures relative to market value.

We include all common stocks listed on the NYSE and Amex, as well as those listed on Nasdaq in our sample. Portfolios are formed at the end of March each year, allowing threemonth's time between the end of a firm's fiscal year and the public disclosure of its lobbying activities for the market to react to the information. ${ }^{15}$ Stocks of firms that lobby are assigned to one of five portfolios based on their ranked lobbying intensity. We keep stocks of nonlobbying firms in a separate category for comparison.

\footnotetext{
${ }^{15}$ The mandatory corporate filings are disclosed on the Senate website, generally within two months of filing, see http://www.senate.gov/legislative/Public_Disclosure/database_download.htm
} 
We then calculate each portfolio's average annual buy-and-hold return over each year from one to three years after portfolio formation. We use buy-and-hold return instead of periodic (monthly) rebalancing because it better resembles investors' actual investment pattern. We also calculate each portfolio's average annual buy-and-hold return in excess of the equally weighted return ${ }^{16}$ on a control portfolio of stocks with zero lobby spending matched by firm size and book-to-market in the first through third post-formation years. There are six ranks by size and five ranks by book-to-market ratio resulting in 30 control portfolios. The ranking by book-to-market is based on quintile breakpoints over all stocks, and the size rankings are based on six quantiles of market capitalization. Each stock's return is measured net of the buy and-hold return on its control portfolio of firms that do not lobby. An implicit assumption of this matching approach is that, absent lobbying, the expected returns of firms that lobby and those in the respective control portfolios are similar. Hence, to the extent there are other omitted systematic determinants of expected returns, our results may need to be qualified.

Table VII reports the returns and characteristics of portfolios classified by lobbying expenditure relative to assets. As shown in Panel C of Table VII, both book-to-market and sales-to-market ratios of the firms that lobby are lower than non-lobbying firms. This could indicate that firms that lobby have relatively high intangible assets that do not appear on their balance sheets, or that such firms are star performers. The earnings-to-price ratio, dividend yield and return on equity of lobbying and non-lobbying groups are not significantly different from each other. Also, note that firms that lobby tend to be much bigger than non-lobbying firms, consistent with Olson (1965).

Panel A of Table VII reports the raw returns before and after portfolio formation and Panel B reports excess returns are calculated after controlling for firm characteristics such as size and book-to-market ratio. It appears that only firms in the highest lobbying intensity quintile (group 5) consistently outperform non-lobbying firms once we focus on excess returns. The excess returns for the highest lobbying intensity portfolio appear substantial. For instance, the average annual return over three-year period after portfolio formation for the

\footnotetext{
${ }^{16}$ For robustness checks, we also construct value-weighted returns on the control portfolio and the results remain little changed.
} 
highest ranked portfolio is 5.5 percent per year, with the highest return in the first year following portfolio formation. The difference in the mean excess returns between the highest ranked lobbying intensity quintile and non-lobbying group is statistically significant at the $1 \%$ level (two-tailed t test $=3.44$ ).

These results suggest that the stock market does not initially fully incorporate the value of corporate lobbying activities. If the stock price fully captures the value of a firm's lobbying activities, we would not find an association between lobbying intensity and future stock returns. The results also lessen the plausibility of causality running from performance to lobbying given that reverse causality would imply that managers accurately forecast profitability (excess market returns) three years into the future.

Table VIII repeats this analysis for portfolios sorted by lobbying expenditures relative to market value of equity. ${ }^{17}$ Results here are similar, though with some nuances; particularly for those firms with the highest lobbying intensity. Over the three years prior to portfolio formation, the average raw annual return of stocks ranked in the top quintile by lobbying relative to market is the lowest (13.91 percent, panel A) across the other four lobbying portfolios. In comparison, stocks of firms that do no lobbying have an average return over the same period of 22.54 percent per year. The earnings of stocks in quintile 5 are also the lowest in the table (Panel C). However, the stocks in the top quintile portfolio perform well in the years following portfolio formation. These firms earn a 35.90 percent average raw return in the first subsequent year, compared to 29.70 percent for stocks with no lobbying, and the difference is more noticeable when comparing excess returns. This indicates possible underpricing of actively lobbying firms. In other words, the market may fail to give enough credit to past losers that are investing heavily in corporate lobbying. The average annual excess rate of return over the three years following portfolio formation is 6.74 percent for the top lobbying quintile, while the non-lobbying firms earn essentially zero average excess returns. The difference in the mean excess returns between the two extreme groups is statistically significant at the $1 \%$ level (two-tailed $t$ test $=4.04)$. This rebound effect is something also noted by Chan et al. (2001) for high R\&D firms.

\footnotetext{
${ }^{17} \mathrm{We}$ also examined the stock returns for portfolios sorted by lobbying expenditures relative to sales. Overall, the results support our findings in Tables VII and VIII and again reveal an association between lobbying intensity and future stock returns.
} 
We investigate this rebound effect further in Table IX, using a two-way sort (first by lobbying intensity, then by past returns) to capture the influence of both past returns and lobbying intensity (measured relative to assets). Specifically, we examine whether past losers who spend heavily on lobbying tend to be undervalued. Within each of the portfolios sorted by lobbying intensity, we assign a stock to one of two equally sized groups, based on its rate of return over the three years prior to portfolio formation. Each stock's return is measured net of the return on a control portfolio matched on size, book-to-market, as well as its past threeyear return. The table reports equally weighted excess returns on each portfolio. Within each quintile by lobbying expenditures relative to assets except for groups 2 and 4, past losers experience higher excess return in the first year post portfolio formation than past winners. However, the results become weaker in the three-year post portfolio formation period where only past losers in groups 2 and 3 outperform past winners. Overall, the results provide evidence of market mispricing of lobbying activities.

\section{3.c Post-Sample Analysis: Citizens United}

In this section we examine whether the market returns of lobbying firms relative to firms without lobbying expenses differed significantly following the landmark U.S. Supreme Court decision in the Citizens United case. ${ }^{18}$ So far we have argued that including the Global Financial Crisis and beyond may require arguably less defensible additional econometric assumptions regarding the stability of the data generation process; hence up to now we have focused on the pre-crisis time period. However, given that the Citizens United decision was widely regarded as unexpected as well as controversial, a closer look at its effects seems warranted. Specifically, in this section we ask whether it is possible to discern a change in the relative financial performance of lobbying firms (measured by market returns) around the time of the Citizens United decision using a differences-in-differences econometric framework. $^{19}$

\footnotetext{
${ }^{18}$ Briefly, the Citizens United Supreme Court decision ruled that the U.S. federal government's prohibition on direct corporate spending for advocacy violated the First Amendment to the U.S. Constitution. The decision left in place existing bans against corporate and union donations to candidates or political parties (so-called 'soft' donations').

${ }^{19}$ Some admittedly simplistic evidence against a large (positive) impact of the Citizens United decision on lobbying activity is that (a) the total amounts spent on lobbying peaked in 2009 , or 2010, and (b) the number of lobbyists peaked even earlier (in 2007), and both have been trending downward since then (see http://www.opensecrets.org/lobby/).
} 
It seems safe to say that the Citizens United decision has led to a cottage-industry of legal scholarship on its effects. However, interestingly, Werner (2011) is the only study we are aware of which attempts to evaluate the market (i.e., stock market) reaction to the decision. Werner (2010, p. 124) summarizes the possibilities: "the decision could be viewed as a boon to corporations (the popular view), the decision could serve as an inconvenient drain on corporate coffers (the contrarian view), or the decision simply could have no effect...", and he adopts an event study methodology to examine how the market interpreted the decision. Werner's sample differs from ours in that he selects 448 firms from the Fortune 500 (based on data availability and a desire to exclude firms with known confounding announcements), whereas our sample includes all firms. More importantly, Werner focuses his event study on abnormal returns, i.e., his null hypothesis is that lobbying firms outperform the market subsequent to the Citizens United decision. However, a moment's reflection suggests that since lobbying firms account for 358 out of his total sample of 448 firms (i.e., 80\%), they effectively are the market; thus his research design biases against finding statistical differences. Perhaps not surprisingly, Werner (2010) finds no impact of the Citizens United decision.

Given these considerations, our approach here is to compare (raw) returns of lobbying firms to firms that do not lobby, in the periods immediately before and after the Citizens United decision, i.e., we employ a difference-in-differences identification strategy. ${ }^{20} \mathrm{We}$ updated our sample of lobbying data from the Center for Responsive Politics (CRP), and we collected stock return data from the Center for Research in Security Prices (CRSP). For completeness we consider three estimation windows surrounding the Citizens United decision (3 months, 2 months, and 1 month), and two post-Citizens United holding periods ( 1 day and 1 week), and we defined 'lobbying' firms in two ways: (a) those that lobbied in 2009, or (b) those that lobbied in three out of the five years prior to the Citizens United decision. In particular, we estimate the following regression, and present the results in Table X: Ret $_{i t}=\alpha+\beta_{1}$ lobby $+\beta_{2}$ lobby $*$ Post Citizens United $+\gamma$ Post Citizens United $+\varepsilon_{i t}$ Variable definitions are as follows: Ret $_{i t}=$ daily returns from CRSP; $\alpha=$ an intercept; lobby $=$

\footnotetext{
${ }^{20}$ Again, we thank a referee for suggesting this approach.
} 
a dummy variable indicating firms with non-zero lobbying expenditures; Post Citizens United $=$ a dummy variable taking the value 0 in the time periods prior to January 21,2010 , and 1 from January 22, 2010 on; lobby*Post Citizens United = an interaction dummy.

We are most interested on the estimated coefficient on this interaction $\left(\beta_{2}\right)$, since statistical significance would indicate whether lobbying firms perform relatively better or worse subsequent to the Citizen United decision. The evidence in Table $\mathrm{X}$ however, does not support an effect of firms that lobby relative to firms that do not in the post-Citizens United sample. Perhaps this should not come as a surprise. First, as Werner (2010) noted, firms may be reluctant to make dramatic changes to their lobbying in a new era of the 'sky's the limit' lobbying. Alternately, the lack of a statistical significant difference between lobbying and non-lobbying firms may simply reflect that the Citizens United decision did not favor firms with prior lobbying efforts; it affects potential future entrants as well.

\section{Conclusions}

There is growing interest in the political activities of corporations. To date, the overwhelming focus of the financial press and research among academics is on corporate political contributions. Contributions however, account for only a small part of corporate political activities - which are not corporate expenses at all since they are, in fact, made by individuals. We document that lobbying expenses are by far the largest form of corporate political activity in the United States. Measured by number of firms engaged, or by dollar amounts spent, lobbying activities far outweigh corporate PAC or the (now banned) corporate soft-money donations. Moreover, this paper uses lobbying data that became publicly available after the passing of the Lobbying Disclosure Act of 1995 to examine the financial implications of this dominant category of corporate political activity.

We present several findings on the relation between corporate financial performance and lobbying. First, based on a pooled regression including all firms (i.e., those with zero and those with positive lobbying spending) we find evidence that lobbying expenditures are on average positively correlated with financial performance. We report several robustness and sensitivity analyses, including various measures of financial performance and alternative empirical specifications. Our results appear robust to several different empirical specifications, and several measures of financial performance, though they are weaker when focusing on 
cash from operations.

Some of the more interesting findings appear when we take a portfolio approach and consider stock market returns. Here, we compare the returns of firms that lobby based on their lobbying intensity, to the returns generated by portfolios of non-lobbying firms. We find that portfolios of firms with the highest lobbying intensities outperform their benchmarks of nonlobbying firms. We also show that increases in lobbying tend to follow poor performance, but what we observe is not simply a mean reversion in returns. Firms with the highest lobbying intensity outperform other firms with similar mean reversion in returns.

Many articles in the financial press suggest that the returns to lobbying are large. Results here also indicate positive returns. As noted above, a natural follow-up question is what keeps even more firms from engaging in lobbying activities? Again, part of the answer may be that specific opportunities arise discretely, and for specific sectors; additional lobbying in unaffected sectors would be pointless. Also, as Kerr, Lincoln, and Mishra (2011) stress, the existence of substantial entry costs can restrict lobbying; this explanation cannot be ruled out and is consistent with our findings. Our portfolio results however, suggest a more nuanced answer: i.e., our analysis of firm-level lobbying data suggests that, in fact, most firms do not enjoy superior financial performance as a result of lobbying. Specifically, we find that only firms that have been willing to commit to the highest lobbying intensities have outperformed their peers. Firms in this category earned an excess return of $5.5 \%$ over the three years following portfolio formation, while the rest of the firms earned essentially a zero excess return. Clearly, not all firms can be in the top-intensity group. Additionally, the relative opacity of lobbying disclosures may have historically obscured its benefits, which suggests that going forward we should expect apparent rents to be dissipated via either greater lobbying spending among all participants, or by new entrants. 


\section{REFERENCES}

Agrawal, A., Knoeber, C., 2001. Do some outside directors play a political role? Journal of Law and Economics 44, 179-198.

Alexander, R., Scholz, S., Mazza, S., 2009. Measuring rates of return for lobbying expenditures: an empirical analysis under the American jobs creation act. Journal of Law and Politics 25(4), 401-457.

Amir, E., Lev, B. 1996. Value-relevance of nonfinancial information: the wireless communications industry. Journal of Accounting and Economics 22, 3-30.

Angrist, J., Pischke, J. 2009. Mostly Harmless Econometrics: an empiricist's companion. Princeton University Press.

Ansolabehere, S., de Figueiredo, J. Snyder, J. Jr. 2003. Why is there so little money in U.S. politics? Journal of Economic Perspectives 17, 105-30.

Ansolabehere, S., Snyder, J., Ueda, M. 2004. Did firms profit from soft money? Election Law Journal 3(2), 193-198.

Bartlett, D., Steele, J., 1988. The great tax give-away. Special section of the Philadelphia Inquirer April 10-16 and September 25-26.

Adelino, M., Dinc S., 2013. Corporate distress and lobbying: evidence from the stimulus act. Forthcoming, Journal of Financial Economics.

Bebchuk, L., Cohen, A., Ferrel, A. 2009. What matters in corporate governance? Review of Financial Studies, 22, 784-827.

Bonardi, J., Holburn, G., Vanden Bergh, R. 2006. Nonmarket strategy performance: evidence from U.S. electric utilities. Academy of Management Journal 49(6), 1209-1228.

Brasher, H., Lowery, D. The corporate context of lobbying activity. Business and Politics 8(1), http://www.bepress.com/bap/vol8/iss1/art1.

Chan, L., Lakonishok, J., Sougiannis, T. 2001. The stock market valuation of research and development expenditures. Journal of Finance 56, 2431-2456.

Claessens, S., Feijen, E., Laeven, L., 2008. Political connections and preferential access to finance: The role of campaign contributions, Journal of Financial Economics, 88(3), $554-580$.

Coates IV, J. 2012, Corporate politics, governance, and value before and after citizens united. Journal of Empirical Legal Studies 9(4), 657-696.

Cooper, M., Gulen, H., Ovtchinnikov, A. 2010. Corporate political contributions and stock returns, Journal of Finance 65(2), 687-724.

de Figueiredo, J, Tiller, E. 2001. The structure and conduct of lobbying: an empirical analysis of corporate lobbying at the federal communications commission. Journal of Economics and Management Strategy 10(1), 91-122.

de Figueiredo, J., Silverman, B. 2006. Academic earmarks and the returns to lobbying. Journal of Law and Economics, 49(2), 597-626. 
Faccio, M. 2006. Politically connected firms. American Economic Review 96(1), 369-386.

Faccio, M., Parsley, D. 2009. Sudden deaths: taking stock of geographic ties. Journal of Financial and Quantitative Analysis, 44(3): 683-718.

Faccio, M., Masulis, R., McConnell, J. 2006. Political connections and corporate bailouts. Journal of Finance, 61(6), 2597-2635.

Fama E.F. and K. R. French, 1997. Industry costs of equity. Journal of Financial Economics. 43: 153-193.

Fan, J., Wong, T., Zhang, T. 2007. Politically-connected CEOs, corporate governance and post-IPO performance of China's newly partially privatized firms. Journal of Financial Economics, 84(2), 330-357.

Fisman, R. 2001. Estimating the value of political connections. American Economic Review, 91, 1095-1102.

Fortune Magazine. Make 150,000\% Today! Jan. 27, 2006.

Goldman, E., Rocholl, J., So, J. 2009. Do politically connected boards affect firm value? Review of Financial Studies, 22(6), 2331-2360.

Goldman, E., So, J. , Rocholl, J. 2012. Political connections and the allocation of procurement contracts. Forthcoming, Review of Finance.

Gompers, P., Ishii, J., Metrick, A. 2003. Corporate governance and equity prices. Quarterly Journal of Economics 118(1), 107-156.

Gordon, S., and Hafer, C. 2005. Flexing muscle: Corporate political expenditures as signals to the bureaucracy. American Political Science Review 99 (2), 245-261.

Grossman G., Helpman, E. 1994. Protection for sale. American Economic Review 84(4), 833850.

Grossman G., Helpman, E. 2001. Special Interest Politics. Cambridge and London: MIT Press.

Hill, M., Kelly, G.,Lockhart, G., Van Ness, R. 2013. Determinants and effects of corporate lobbying. Financial Management 42(4), 931-957.

Hillman, A. Keim, G., Schuler, D. 2004. Corporate political activity: a review and research agenda. Journal of Management 30(6), 837-857.

Igan, D., Mishra, P., Tressel, T. 2009. A fistful of dollars: lobbying and the financial crisis. IMF working paper 09287.

Jayachandran, S. 2006. The Jeffords effect. Journal of Law and Economics 49(2), 397-425.

Kerr, W., Lincoln, W., Mishra, P. 2011. The dynamics of firm lobbying. NBER working paper 17577.

Kim, J. 2008. Corporate lobbying revisited. Business and Politics 10(2). http://www.bepress.com/bap/vol10/iss2/art3.

Leuz, C., Oberholzer-Gee, F. 2006. Political relationships, global financing, and corporate transparency: evidence from Indonesia, Journal of Financial Economics 81, 411 - 439. 
Lev, B., Sougiannis, T. 1996. The capitalization, amortization, and value-relevance of R\&D. Journal of Accounting and Economics 21, 107-138.

Lux, S., Crook, T., Woer, D. 2011. Mixing business with politics: a meta-analysis of the antecedents and outcomes of corporate political activity. Journal of Management 37(1), 223-247.

Milyo, J., Primo, D., Groseclose, T. 2000. Corporate PAC campaign contributions in perspective. Business and Politics 2(1), 75-88.

Moulton, B. 1986. Random group effects and the precision of regression estimates. Journal of Econometrics 32, 385-397.

Mayda, A., Ludema, R., Mishra, P. 2010. Protection for free? the political economy of U.S. tariff suspensions. IMF Working Paper 10/211.

Nichols, A. 2007. Causal inference with observational data. The Stata Journal 7(4), 507-541.

Olson, M. 1965. The logic of collective action: public goods and the theory of groups, Harvard University Press.

Richter, B. K., Samphantharak, K., and Timmons, J. F. 2009. Lobbying and taxes, American Journal of Political Science 53(4), 893-909.

Snyder, J. Jr. 1992. Long-term investing in politicians; or, give early, give often. Journal of Law \& Economics 35, 15-43.

Sougiannis, T. 1994. The accounting based valuation of corporate R\&D. Accounting Review 69 (1), 44-68.

Stigler G. 1971. The theory of economic regulation. Bell Journal of Economics and Management Science 2(1), 3-21.

Washington Post. (by Birnbaum, J. H ). Clients' rewards keep K street lobbyists thriving. February 14, 2006.

Werner, T. 2011. The sound, the fury, and the nonevent: business power and market reactions to the citizens united decision. American Politics Research 39(1), 118-141.

Wirl, F. 1994. They dynamics of lobbying - a differential game. Public Choice 80, 307-323.

Yu F., Yu, X. 2011. Corporate lobbying and fraud detection. Journal of Financial and Quantitative Analysis, 46(6), 1865-1891. 
Figure 1: Total and Average Annual Lobbying Spending in the period of 1998-2005

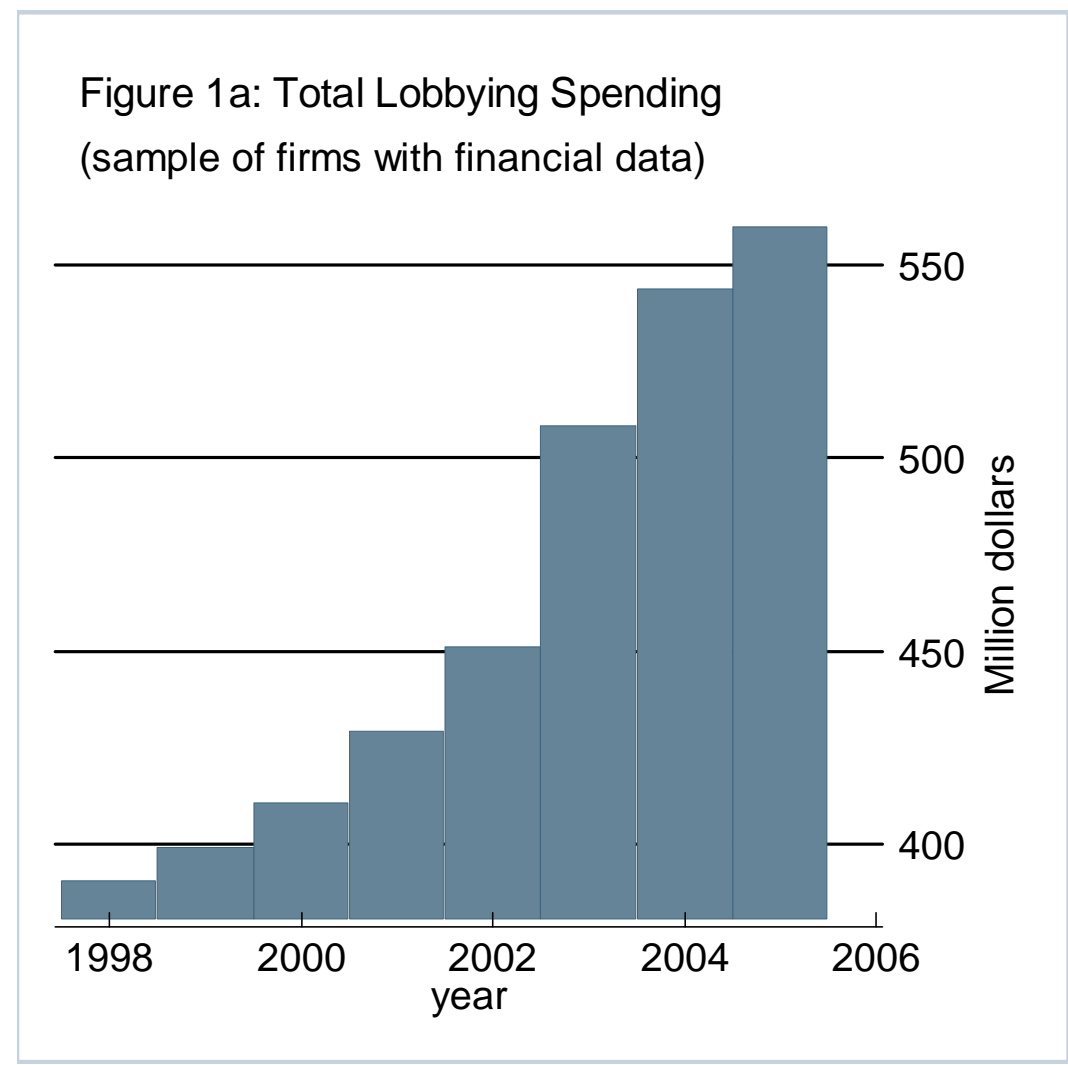

Figure 1b: Average Annual Lobbying Spending (sample of firms with financial data)

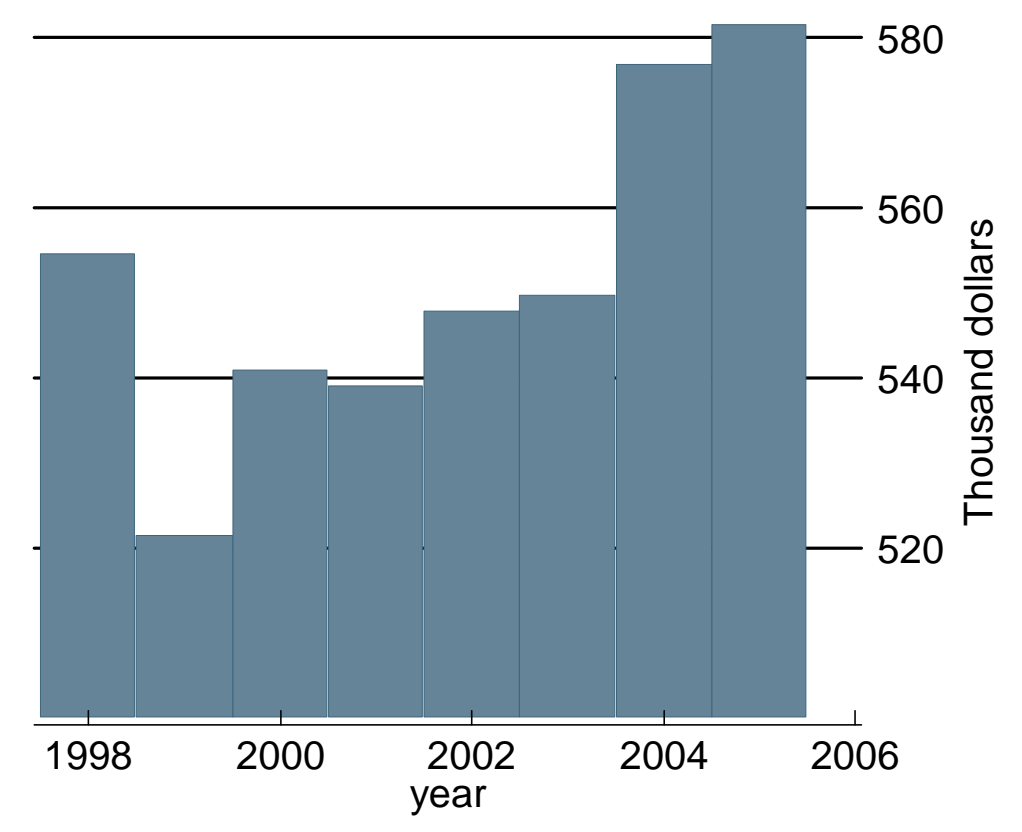




\section{Table I: Three Categories of Corporate Political Involvement}

Panel A: Lobbying Activities (Annual amounts)

$\begin{array}{rrrrrrrr}\text { Mear } & \text { \# of firms } & \text { Mean (\$) } & \begin{array}{r}\text { Std Dev } \\ \text { (million \$) }\end{array} & \text { Min }(\$) & \begin{array}{r}\text { Max } \\ \text { \# of firms in }\end{array} & \begin{array}{r}\text { Comp firms in } \\ \text { Compustat } \\ \text { that lobby }\end{array} \\ 1998 & 704 & 554,628 & 1.40 & 10,000 & 23 & 10765 & 6.54 \% \\ 1999 & 765 & 521,482 & 1.23 & 10,000 & 14.7 & 10795 & 7.09 \% \\ 2000 & 759 & 540,833 & 1.25 & 10,000 & 16 & 10347 & 7.34 \% \\ 2001 & 796 & 539,003 & 1.24 & 10,000 & 15.4 & 9745 & 8.17 \% \\ 2002 & 823 & 547,894 & 1.23 & 10,000 & 14 & 9292 & 8.86 \% \\ 2003 & 925 & 549,761 & 1.28 & 10,000 & 17 & 9024 & 10.25 \% \\ 2004 & 943 & 576,744 & 1.35 & 10,000 & 17.2 & 8716 & 10.82 \% \\ 2005 & 963 & 581,447 & 1.41 & 10,000 & 18.8 & 8167 & 11.79 \%\end{array}$

Panel B: PAC Contributions (Election Cycle amounts)

$\begin{array}{rrrrrr}\text { Year } & \text { \# of firms } & \text { Mean (\$) } & \begin{array}{r}\text { Std Dev } \\ \text { (million \$) }\end{array} & \text { Min (\$) } & \begin{array}{r}\text { Max } \\ \text { (million \$) }\end{array} \\ 1998 & 430 & 84,618 & 0.14 & 350 & 1.5 \\ 2000 & 487 & 94,036 & 0.16 & 125 & 1.8 \\ 2002 & 509 & 106,190 & 0.18 & 200 & 1.6 \\ 2004 & 527 & 127,146 & 0.22 & 150 & 2.1\end{array}$

Panel C: Soft-Money Contributions (Election Cycle amounts)

$\begin{array}{rrrrrr}\text { Year } & \text { \# of firms } & \text { Mean (\$) } & \begin{array}{r}\text { Std Dev } \\ \text { (million \$) }\end{array} & \begin{array}{r}\text { Max } \\ \text { Min } \$ \text { ) }\end{array} & \text { (million \$) } \\ 1998 & 324 & 116,607 & 0.21 & 250 & 2.4 \\ 2000 & 420 & 197,834 & 0.34 & 220 & 2.4 \\ 2002 & 423 & 195,574 & 0.38 & 250 & 2.9\end{array}$


Table II: Top 20 Lobbying Spenders in 2005 (in \$millions)

Variable definitions: Assets = total assets; Sales = net sales; IBEI = income before extraordinary items; lobbying spending = lobbying expenditures.

\begin{tabular}{|c|c|c|c|c|c|c|}
\hline Rank & Company Name & Industry & Assets & Sales & IBEI & $\begin{array}{l}\text { Lobbying } \\
\text { Spending }\end{array}$ \\
\hline 1 & General Electric & Conglomerates & 673,342 & 148,019 & 18,275 & 18.77 \\
\hline 2 & Altria Group & Cigarettes & 107,949 & 68,920 & 10,668 & 13.64 \\
\hline 3 & Northrop Grumman & $\begin{array}{l}\text { Search, detection, navigation, } \\
\text { guidance, aeronautical systems }\end{array}$ & 34214 & 30721 & 1383 & 13.60 \\
\hline 4 & Southern Co & Electric services & 39,877 & 13,554 & 1,621 & 12.96 \\
\hline 5 & Boeing Co & Aircraft & 60,058 & 54,845 & 2,562 & 9.24 \\
\hline 6 & $\mathrm{AIG}$ & Life insurance & 853,370 & 108,340 & 10,477 & 8.50 \\
\hline 7 & General Motors & Motor vehicles \& car bodies & 476,078 & 190,215 & $-10,458$ & 7.76 \\
\hline 8 & Motorola Inc & $\begin{array}{l}\text { Radio, TV broadcast, } \\
\text { communication equipment }\end{array}$ & 35,649 & 36,843 & 4,599 & 7.59 \\
\hline 9 & Lockheed Martin & $\begin{array}{l}\text { Guided missiles \& space vehicles } \\
\& \text { parts }\end{array}$ & 27,744 & 37,213 & 1,825 & 7.34 \\
\hline 10 & Exxon Mobil & Petroleum refining & 208,335 & 328,213 & 36,130 & 7.02 \\
\hline 11 & Verizon Communications & $\begin{array}{l}\text { Telephone communications } \\
\text { except radiotelephone }\end{array}$ & 168,130 & 75,112 & 7,397 & 6.76 \\
\hline 12 & Pfizer Inc & Pharmaceutical Preparations & 117,565 & 51,298 & 8,094 & 6.49 \\
\hline 13 & Amgen Inc & $\begin{array}{l}\text { Biological products except } \\
\text { diagnostic substances }\end{array}$ & 29,297 & 12,430 & 3,674 & 5.72 \\
\hline 14 & Johnson \& Johnson & Pharmaceutical Preparations & 58,025 & 50,514 & 10,411 & 5.38 \\
\hline 15 & DaimlerChrysler & Motor vehicles \& car bodies & 238,773 & 177,365 & 3,376 & 5.34 \\
\hline 16 & ConocoPhillips & Petroleum refining & 106,999 & 162,405 & 13,640 & 5.10 \\
\hline 17 & Bristol-Myers Squibb & Pharmaceutical & 28,138 & 19,207 & 2,992 & 5.04 \\
\hline 18 & GlaxoSmithKline & Pharmaceutical & 46,748 & 37,855 & 8,059 & 4.86 \\
\hline 19 & SBC Communications & $\begin{array}{l}\text { Telephone communications } \\
\text { except radiotelephone }\end{array}$ & 145,632 & 43,862 & 4,786 & 4.84 \\
\hline 20 & Ford Motor Co & Motor vehicles \& car bodies & 269,476 & 177,089 & 2,228 & 4.80 \\
\hline
\end{tabular}




\section{Table III: Average Lobby Spending by Industry Group and Year}

\begin{tabular}{|c|c|c|c|c|c|c|c|c|c|c|}
\hline $\begin{array}{l}\text { 2-digit } \\
\text { SIC }^{a}\end{array}$ & Industry & 1998 & 1999 & 2000 & 2001 & 2002 & 2003 & 2004 & 2005 & Average \\
\hline 01-09 & $\begin{array}{l}\text { Agriculture, } \\
\text { forestry \& fishing }\end{array}$ & $\begin{array}{r}0.200 \\
(2)^{\mathrm{b}}\end{array}$ & $\begin{array}{r}0.230 \\
(5)\end{array}$ & $\begin{array}{r}0.502 \\
(3)\end{array}$ & $\begin{array}{r}0.139 \\
(4)\end{array}$ & $\begin{array}{r}0.319 \\
(4)\end{array}$ & $\begin{array}{r}0.397 \\
(4)\end{array}$ & $\begin{array}{r}0.476 \\
(4)\end{array}$ & $\begin{array}{r}0.589 \\
(4)\end{array}$ & $\begin{array}{r}0.357 \\
(4)\end{array}$ \\
\hline $10-19$ & $\begin{array}{l}\text { Mining \& } \\
\text { construction }\end{array}$ & $\begin{array}{r}0.410 \\
(28)\end{array}$ & $\begin{array}{r}0.403 \\
(30)\end{array}$ & $\begin{array}{r}0.420 \\
(31)\end{array}$ & $\begin{array}{r}0.329 \\
(33)\end{array}$ & $\begin{array}{r}0.376 \\
(36)\end{array}$ & $\begin{array}{r}0.253 \\
(45)\end{array}$ & $\begin{array}{r}0.284 \\
(42)\end{array}$ & $\begin{array}{r}0.269 \\
(43)\end{array}$ & $\begin{array}{r}0.343 \\
(36)\end{array}$ \\
\hline $20-29$ & Manufacturing & $\begin{array}{l}0.725 \\
(141)\end{array}$ & $\begin{array}{l}0.765 \\
(147)\end{array}$ & $\begin{array}{l}0.693 \\
(150)\end{array}$ & $\begin{array}{l}0.657 \\
(152)\end{array}$ & $\begin{array}{l}0.738 \\
(144)\end{array}$ & $\begin{array}{l}0.656 \\
(163)\end{array}$ & $\begin{array}{l}0.671 \\
(166)\end{array}$ & $\begin{array}{l}0.744 \\
(175)\end{array}$ & $\begin{array}{l}0.706 \\
(155)\end{array}$ \\
\hline $30-39$ & Manufacturing & $\begin{array}{l}0.628 \\
(156)\end{array}$ & $\begin{array}{l}0.530 \\
(164)\end{array}$ & $\begin{array}{l}0.548 \\
(162)\end{array}$ & $\begin{array}{l}0.528 \\
(175)\end{array}$ & $\begin{array}{l}0.484 \\
(200)\end{array}$ & $\begin{array}{l}0.480 \\
(226)\end{array}$ & $\begin{array}{l}0.494 \\
(238)\end{array}$ & $\begin{array}{l}0.481 \\
(234)\end{array}$ & $\begin{array}{l}0.522 \\
(194)\end{array}$ \\
\hline $40-49$ & $\begin{array}{l}\text { Transportation \& } \\
\text { utilities }\end{array}$ & $\begin{array}{l}0.494 \\
(159)\end{array}$ & $\begin{array}{l}0.495 \\
(166)\end{array}$ & $\begin{array}{l}0.519 \\
(163)\end{array}$ & $\begin{array}{l}0.507 \\
(167)\end{array}$ & $\begin{array}{l}0.554 \\
(160)\end{array}$ & $\begin{array}{l}0.628 \\
(158)\end{array}$ & $\begin{array}{l}0.672 \\
(150)\end{array}$ & $\begin{array}{l}0.663 \\
(150)\end{array}$ & $\begin{array}{l}0.567 \\
(159)\end{array}$ \\
\hline $50-59$ & Wholesale \& retail & $\begin{array}{r}0.215 \\
(38)\end{array}$ & $\begin{array}{r}0.208 \\
(40)\end{array}$ & $\begin{array}{r}0.235 \\
(46)\end{array}$ & $\begin{array}{r}0.487 \\
(42)\end{array}$ & $\begin{array}{r}0.242 \\
(38)\end{array}$ & $\begin{array}{r}0.297 \\
(42)\end{array}$ & $\begin{array}{r}0.293 \\
(45)\end{array}$ & $\begin{array}{r}0.301 \\
(51)\end{array}$ & $\begin{array}{r}0.285 \\
(43)\end{array}$ \\
\hline $60-69$ & $\begin{array}{l}\text { Finance, insurance } \\
\& \text { real estate }\end{array}$ & $\begin{array}{r}0.671 \\
(91)\end{array}$ & $\begin{array}{l}0.567 \\
(107)\end{array}$ & $\begin{array}{l}0.615 \\
(100)\end{array}$ & $\begin{array}{l}0.673 \\
(103)\end{array}$ & $\begin{array}{l}0.830 \\
(103)\end{array}$ & $\begin{array}{l}0.837 \\
(128)\end{array}$ & $\begin{array}{l}0.893 \\
(125)\end{array}$ & $\begin{array}{l}0.878 \\
(120)\end{array}$ & $\begin{array}{l}0.745 \\
(110)\end{array}$ \\
\hline 70-79 & $\begin{array}{l}\text { Personal \& } \\
\text { business services }\end{array}$ & $\begin{array}{r}0.331 \\
(54)\end{array}$ & $\begin{array}{r}0.318 \\
(64)\end{array}$ & $\begin{array}{r}0.344 \\
(70)\end{array}$ & $\begin{array}{r}0.350 \\
(83)\end{array}$ & $\begin{array}{r}0.320 \\
(90)\end{array}$ & $\begin{array}{l}0.335 \\
(100)\end{array}$ & $\begin{array}{l}0.381 \\
(107)\end{array}$ & $\begin{array}{l}0.382 \\
(114)\end{array}$ & $\begin{array}{r}0.345 \\
(85)\end{array}$ \\
\hline $80-89$ & $\begin{array}{l}\text { Healthcare \& } \\
\text { other services }\end{array}$ & $\begin{array}{r}0.132 \\
(29)\end{array}$ & $\begin{array}{r}0.122 \\
(34)\end{array}$ & $\begin{array}{r}0.195 \\
(27)\end{array}$ & $\begin{array}{r}0.201 \\
(31)\end{array}$ & $\begin{array}{r}0.190 \\
(40)\end{array}$ & $\begin{array}{r}0.200 \\
(52)\end{array}$ & $\begin{array}{r}0.268 \\
(57)\end{array}$ & $\begin{array}{r}0.310 \\
(63)\end{array}$ & $\begin{array}{r}0.202 \\
(42)\end{array}$ \\
\hline $90-99$ & $\begin{array}{l}\text { Public } \\
\text { administration }\end{array}$ & $\begin{array}{r}2.395 \\
(3)\end{array}$ & $\begin{array}{r}1.591 \\
(5)\end{array}$ & $\begin{array}{r}5.353 \\
(3)\end{array}$ & $\begin{array}{r}3.883 \\
(4)\end{array}$ & $\begin{array}{r}2.608 \\
(5)\end{array}$ & $\begin{array}{r}4.301 \\
(4)\end{array}$ & $\begin{array}{r}3.864 \\
(5)\end{array}$ & $\begin{array}{r}3.936 \\
(5)\end{array}$ & $\begin{array}{r}3.491 \\
(4)\end{array}$ \\
\hline
\end{tabular}

This table reports data from the Center for Responsive Politics. The CRP data includes lobbying, PAC, and soft-money contributions as distinct categories. CRP reports lobbying expenses by calendar year and both PAC and soft-money contributions by election cycle

${ }^{\mathrm{a}} \mathrm{SIC}$ classification is from the U.S. Department of Labor at http://www.osha.gov

${ }^{\mathrm{b}}$ Number of firms is in parenthesis. 


\section{Table IV Descriptive Statistics}

(Firms with fiscal years ending in December)

\begin{tabular}{lcrrrr}
\hline Variable & Obs & \multicolumn{1}{c}{ Mean } & Std. Dev. & Min & Max \\
\hline \multicolumn{2}{l}{ Panel A: Firms } & with non-zero lobbying spending & & \\
IBEI & 4,400 & 507.86 & $1,977.71$ & $-25,779.47$ & $36,130.00$ \\
NI & 4,400 & 501.72 & $2,014.38$ & $-25,779.47$ & $36,130.00$ \\
CFO & 4,272 & $1,111.21$ & $3,500.09$ & $-25,658.00$ & $78,470.00$ \\
ASSET & 4,402 & $25,904.71$ & $100,906.42$ & 0.00 & $1,494,037.00$ \\
LOBBY & 4,676 & 0.64 & 1.40 & 0.01 & 18.77 \\
MB & 3,963 & 4.83 & 114.42 & -656.93 & $7,071.35$ \\
PRICE & 4,108 & 35.27 & 71.84 & 0.00 & $1,522.00$ \\
RETURN & 3,292 & 0.14 & 0.63 & -0.94 & 4.16 \\
AIBEI & 3,234 & 56.19 & $1,487.24$ & $-26,472.00$ & $27,357.87$ \\
$\Delta$ NI & 3,234 & 62.31 & $1,525.00$ & $-26,213.00$ & $27,357.87$ \\
$\Delta$ CFO & 3,143 & 134.68 & $1,915.67$ & $-44,739.00$ & $36,706.00$ \\
LLOBBY & 3,461 & 0.04 & 0.63 & -7.55 & 11.39 \\
Panel B: All Compustat firms & & & & \\
IBEI & 53,685 & 108.10 & 924.44 & $-44,574.00$ & $36,130.00$ \\
NI & 53,686 & 104.43 & $1,106.18$ & $-98,696.00$ & $36,130.00$ \\
CFO & 47,362 & 274.95 & $1,734.79$ & $-48,073.47$ & $102,999.81$ \\
ASSET & 53,806 & $6,771.52$ & $50,490.00$ & 0.00 & $1,588,784.81$ \\
MB & 45,685 & 3.55 & 169.50 & $-11,100.00$ & $24,950.20$ \\
PRICE & 57,929 & 29.85 & 970.03 & 0.00 & $88,620.00$ \\
RETURN & 43,798 & 0.16 & 1.08 & -0.98 & 9.00 \\
$\Delta$ IBEI & 43,256 & 14.33 & 755.40 & $-39,679.00$ & $47,720.00$ \\
$\Delta$ NI & 43,255 & 12.49 & $1,108.52$ & $-93,775.00$ & $101,335.00$ \\
$\Delta$ CFO & 38,180 & 24.42 & $1,051.23$ & $-69,093.23$ & $47,370.00$ \\
\hline & & & & &
\end{tabular}


Table V Lobbying and Financial Performance

\begin{tabular}{|c|c|c|c|c|c|c|c|c|c|}
\hline VARIABLES & $\begin{array}{l}\text { (1) } \\
\text { ibei }\end{array}$ & $\begin{array}{l}(2) \\
\text { ibei }\end{array}$ & $\begin{array}{l}\text { (3) } \\
\text { ibei }\end{array}$ & $\begin{array}{l}\text { (4) } \\
\text { ni }\end{array}$ & $\begin{array}{l}(5) \\
\text { ni }\end{array}$ & $\begin{array}{l}\text { (6) } \\
\text { ni }\end{array}$ & $\begin{array}{l}\text { (7) } \\
\text { cfo }\end{array}$ & $\begin{array}{l}(8) \\
\text { cfo }\end{array}$ & $\begin{array}{l}(9) \\
\text { cfo }\end{array}$ \\
\hline $\operatorname{lobby}_{\mathrm{t}-1}$ & $\begin{array}{c}88.437 * * * \\
(4.066)\end{array}$ & $\begin{array}{c}75.368 * * * \\
(4.206)\end{array}$ & $\begin{array}{c}79.636 * * * \\
(3.663)\end{array}$ & $\begin{array}{c}59.430 * * * \\
(2.751)\end{array}$ & $\begin{array}{c}69.887 * * * \\
(3.952)\end{array}$ & $\begin{array}{c}69.708 * * * \\
(3.464)\end{array}$ & $\begin{array}{l}48.207 \\
(1.601)\end{array}$ & $\begin{array}{c}50.144 * * \\
(2.054)\end{array}$ & $\begin{array}{l}37.695 \\
(1.307)\end{array}$ \\
\hline assets & $\begin{array}{c}0.006 * * * \\
(4.863)\end{array}$ & $\begin{array}{c}0.006 * * * \\
(3.996)\end{array}$ & $\begin{array}{c}0.010 * * * \\
(8.934)\end{array}$ & $\begin{array}{c}0.008 * * * \\
(7.144)\end{array}$ & $\begin{array}{c}0.007 * * * \\
(6.469)\end{array}$ & $\begin{array}{c}0.010 * * * \\
(5.444)\end{array}$ & $\begin{array}{c}0.019 * * * \\
(4.481)\end{array}$ & $\begin{array}{c}0.016 * * * \\
(3.971)\end{array}$ & $\begin{array}{c}0.016 * * * \\
(2.785)\end{array}$ \\
\hline market-to-book ratio & $\begin{array}{c}-0.001 \\
(-0.746)\end{array}$ & $\begin{array}{c}0.000 \\
(0.065)\end{array}$ & $\begin{array}{c}-0.001 \\
(-0.711)\end{array}$ & $\begin{array}{c}-0.001 \\
(-0.990)\end{array}$ & $\begin{array}{c}-0.002 \\
(-0.825)\end{array}$ & $\begin{array}{c}-0.003 \\
(-1.037)\end{array}$ & $\begin{array}{c}-0.000 \\
(-0.040)\end{array}$ & $\begin{array}{c}-0.000 \\
(-0.066)\end{array}$ & $\begin{array}{c}-0.001 \\
(-1.308)\end{array}$ \\
\hline dependent variable t $_{t}$ & & $\begin{array}{c}0.270 * * * \\
(9.982)\end{array}$ & $\begin{array}{c}0.256 * * * \\
(8.552)\end{array}$ & & $\begin{array}{c}0.224 * * * \\
(8.710)\end{array}$ & $\begin{array}{c}0.188 * * * \\
(6.275)\end{array}$ & & $\begin{array}{c}0.295 * * * \\
(9.830)\end{array}$ & $\begin{array}{c}0.266^{* * *} \\
(7.855)\end{array}$ \\
\hline dependent $_{\text {variable }}$ t-2 & & & $\begin{array}{c}-0.094 * * * \\
(-2.692)\end{array}$ & & & $\begin{array}{c}-0.044 \\
(-1.569)\end{array}$ & & & $\begin{array}{c}0.023 \\
(0.780)\end{array}$ \\
\hline Observations & 36706 & 35739 & 29574 & 35899 & 34702 & 28489 & 31355 & 30391 & 25025 \\
\hline $\begin{array}{l}\text { No. of firms } \\
\text { R-squared (within) }\end{array}$ & $\begin{array}{r}6986 \\
0.085\end{array}$ & $\begin{array}{l}6951 \\
0.154\end{array}$ & $\begin{array}{c}6598 \\
0.174\end{array}$ & $\begin{array}{c}6938 \\
0.0833\end{array}$ & $\begin{array}{r}6874 \\
0.138\end{array}$ & $\begin{array}{r}6482 \\
0.147\end{array}$ & $\begin{array}{c}0136 \\
0.0979\end{array}$ & $\begin{array}{l}6052 \\
0.181\end{array}$ & $\begin{array}{l}5703 \\
0.149\end{array}$ \\
\hline R-squared (between) & 0.311 & 0.541 & 0.423 & 0.223 & 0.452 & 0.430 & 0.201 & 0.575 & 0.695 \\
\hline R-squared (overall) & 0.274 & 0.526 & 0.444 & 0.222 & 0.464 & 0.416 & 0.248 & 0.618 & 0.688 \\
\hline
\end{tabular}

This table reports OLS estimates of the relationship between lobbying and firm performance. Firm performance is measured by:

$\mathrm{IBEI}=$ income before extraordinary items in year $\mathrm{t}$; $\mathrm{NI}=$ net income in year $\mathrm{t}$; $\mathrm{CFO}=$ cash from operations in year $\mathrm{t}$. Independent variables are: $\mathrm{LOBBY}=$ lobbying spending in year $\mathrm{t}-1$; $\mathrm{MB}=$ market-to-book ratio at the end of year $\mathrm{t}$; ASSET $=$ total assets at the beginning of the year t. The sample includes all stocks on the NYSE, AMEX, and Nasdaq with coverage on the CRSP and COMPUSTAT files annually, for the years 1998-2005. All regressions include firm-level fixed effects, Fama-French industry dummies, and time dummies. Two-tailed t-statistics (adjusted for clustering at the firm level) in the parenthesis under the coefficient estimates. $*, * *$, and $* * *$ indicate the regression coefficients are significantly different from zero at the $10 \%, 5 \%$, and $1 \%$ level, respectively. 
Table VI Lobbying and Financial Performance: first difference specifications

\begin{tabular}{|c|c|c|c|c|c|c|c|c|c|}
\hline VARIABLES & $\begin{array}{c}(1) \\
\Delta \text { ibei } \\
\end{array}$ & $\begin{array}{c}(2) \\
\Delta \text { ibei }\end{array}$ & $\begin{array}{c}(3) \\
\Delta \text { ibei } \\
\end{array}$ & $\begin{array}{l}(4) \\
\Delta \mathrm{ni}\end{array}$ & $\begin{array}{l}(5) \\
\Delta \mathrm{ni}\end{array}$ & $\begin{array}{l}(6) \\
\Delta \mathrm{ni}\end{array}$ & $\begin{array}{c}(7) \\
\Delta \text { cfo } \\
\end{array}$ & $\begin{array}{c}(8) \\
\Delta \text { cfo } \\
\end{array}$ & $\begin{array}{c}(9) \\
\Delta \text { cfo } \\
\end{array}$ \\
\hline lobby $_{\mathrm{t}-1}$ & $\begin{array}{c}35.614^{*} \\
(1.755)\end{array}$ & $\begin{array}{c}67.270 * * \\
(2.456)\end{array}$ & $\begin{array}{l}44.417 \\
(1.124)\end{array}$ & $\begin{array}{c}53.207 * * \\
(2.393)\end{array}$ & $\begin{array}{c}55.900 * * \\
(2.048)\end{array}$ & $\begin{array}{l}39.885 \\
(1.566)\end{array}$ & $\begin{array}{c}-5.357 \\
(-0.255)\end{array}$ & $\begin{array}{l}-19.858 \\
(-0.606)\end{array}$ & $\begin{array}{l}28.541 \\
(0.622)\end{array}$ \\
\hline assets & $\begin{array}{l}0.002 * \\
(1.843)\end{array}$ & $\begin{array}{c}0.006 * * * \\
(6.693)\end{array}$ & $\begin{array}{c}0.009 * * * \\
(7.290)\end{array}$ & $\begin{array}{c}0.002 * * \\
(2.182)\end{array}$ & $\begin{array}{c}0.005^{* * *} \\
(5.200)\end{array}$ & $\begin{array}{c}0.007 * * * \\
(5.654)\end{array}$ & $\begin{array}{l}0.004 * * \\
(2.107)\end{array}$ & $\begin{array}{c}0.005 \\
(1.518)\end{array}$ & $\begin{array}{c}0.015^{* * *} \\
(4.654)\end{array}$ \\
\hline market-to-book ratio & $\begin{array}{c}-0.001 \\
(-0.360)\end{array}$ & $\begin{array}{c}-0.001 \\
(-0.231)\end{array}$ & $\begin{array}{c}0.002 \\
(0.608)\end{array}$ & $\begin{array}{c}-0.003 \\
(-0.858)\end{array}$ & $\begin{array}{c}-0.003 \\
(-0.709)\end{array}$ & $\begin{array}{c}-0.003 \\
(-0.474)\end{array}$ & $\begin{array}{c}-0.001 \\
(-1.034)\end{array}$ & $\begin{array}{c}-0.000 \\
(-0.797)\end{array}$ & $\begin{array}{c}-0.000 \\
(-0.144)\end{array}$ \\
\hline dependent variable $_{t-1}$ & & $\begin{array}{c}-0.348 * * * \\
(-14.423)\end{array}$ & $\begin{array}{c}-0.445 * * * \\
(-14.455)\end{array}$ & & $\begin{array}{c}-0.408 * * * \\
(-21.523)\end{array}$ & $\begin{array}{c}-0.508 * * * \\
(-18.488)\end{array}$ & & $\begin{array}{c}-0.401 * * * \\
(-16.099)\end{array}$ & $\begin{array}{c}-0.526 * * * \\
(-15.226)\end{array}$ \\
\hline dependent variable $_{t-2}$ & & & $\begin{array}{l}-0.299 * * * \\
(-12.193)\end{array}$ & & & $\begin{array}{c}-0.289 * * * \\
(-10.780)\end{array}$ & & & $\begin{array}{c}-0.298 * * * \\
(-10.468)\end{array}$ \\
\hline Observations & 35739 & 29574 & 23056 & 34702 & 28489 & 22040 & 30391 & 25025 & 19395 \\
\hline $\begin{array}{l}\text { No. of firms } \\
\text { R-squared (within) }\end{array}$ & $\begin{array}{c}6951 \\
0.015\end{array}$ & $\begin{array}{r}6598 \\
0.137\end{array}$ & $\begin{array}{r}6023 \\
0.220\end{array}$ & $\begin{array}{c}6874 \\
0.0139\end{array}$ & $\begin{array}{r}6482 \\
0.174\end{array}$ & $\begin{array}{l}5849 \\
0.234\end{array}$ & $\begin{array}{c}6052 \\
0.00297\end{array}$ & $\begin{array}{c}5703 \\
0.148\end{array}$ & $\begin{array}{l}5160 \\
0.227\end{array}$ \\
\hline R-squared (between) & 0.0880 & 0.0686 & 0.0383 & 0.110 & 0.0389 & 0.0442 & 0.0964 & 0.0152 & 0.0307 \\
\hline R-squared (overall) & 0.0300 & 0.0620 & 0.0603 & 0.0256 & 0.0726 & 0.0786 & 0.0157 & 0.0739 & 0.0679 \\
\hline
\end{tabular}

This table reports OLS estimates of the relationship between lobbying and the change in firm performance. Firm performance is measured by: IBEI = income before extraordinary items in year $\mathrm{t}$; $\mathrm{NI}=$ net income in year $\mathrm{t}$; $\mathrm{CFO}=$ cash from operations in year $\mathrm{t}$. Independent variables are: LOBBY = lobbying spending in year $\mathrm{t}-1$; $\mathrm{MB}=$ market-to-book ratio at the end of year $\mathrm{t}$; ASSET $=$ total assets at the beginning of the year $t$. The sample includes all stocks on the NYSE, AMEX, and Nasdaq with coverage on the CRSP and COMPUSTAT files annually, for the years 1998-2005. All regressions include firm-level fixed effects, Fama-French industry, and time dummies. Two-tailed t-statistics (adjusted for clustering at the firm level) in the parenthesis under the coefficient estimates. $* * *$, and $* * *$ indicate the regression coefficients are significantly different from zero at the $10 \%, 5 \%$, and $1 \%$ level, respectively.

$* * * \mathrm{p}<0.01, * * \mathrm{p}<0.05, * \mathrm{p}<0.1$ 


\section{Table VII Returns and Characteristics of Portfolios Classified by Lobbying Expenditure Relative to Assets}

\begin{tabular}{|c|c|c|c|c|c|c|}
\hline Rank & 1(Low) & 2 & 3 & 4 & 5 (High) & $\begin{array}{r}\text { Non- } \\
\text { Lobbying } \\
\end{array}$ \\
\hline \multicolumn{7}{|c|}{ Panel A: Returns before and after portfolio formation } \\
\hline $\begin{array}{l}\text { Average annual return over } 3 \text {-year } \\
\text { period before portfolio formation }\end{array}$ & 0.1681 & 0.1495 & 0.1798 & 0.2653 & 0.2353 & 0.2254 \\
\hline $\begin{array}{l}\text { First year after portfolio formation } \\
\text { Second year after portfolio }\end{array}$ & 0.1148 & 0.1601 & 0.1396 & 0.2088 & 0.3277 & 0.2970 \\
\hline formation & 0.1842 & 0.1612 & 0.2350 & 0.1703 & 0.2488 & 0.2480 \\
\hline Third year after portfolio formation & 0.1491 & 0.1923 & 0.1680 & 0.1714 & 0.2278 & 0.2419 \\
\hline $\begin{array}{l}\text { Average annual return over } 3 \text {-year } \\
\text { period after portfolio formation }\end{array}$ & 0.1494 & 0.1712 & 0.1809 & 0.1835 & 0.2681 & 0.2623 \\
\hline \multicolumn{7}{|c|}{ Panel B: Excess returns before and after portfolio formation } \\
\hline $\begin{array}{l}\text { Average annual return over } 3 \text {-year } \\
\text { period before portfolio formation }\end{array}$ & -0.0381 & -0.0761 & -0.0588 & -0.0071 & -0.0514 & 0.0060 \\
\hline $\begin{array}{l}\text { First year after portfolio formation } \\
\text { Second year after portfolio }\end{array}$ & -0.0263 & 0.0160 & -0.0112 & 0.0481 & 0.1083 & -0.0035 \\
\hline formation & 0.0200 & -0.0123 & 0.0641 & 0.0003 & 0.0230 & -0.0025 \\
\hline Third year after portfolio formation & -0.0142 & 0.0215 & -0.0031 & 0.0036 & 0.0349 & -0.0011 \\
\hline $\begin{array}{l}\text { Average annual return over } 3 \text {-year } \\
\text { period after portfolio formation }\end{array}$ & -0.0068 & 0.0084 & 0.0166 & 0.0173 & 0.0554 & -0.0024 \\
\hline \multicolumn{7}{|c|}{ Panel C: Characteristics of Portfolios } \\
\hline Average number of observations & 485 & 491 & 490 & 491 & 488 & 18,834 \\
\hline Lobby spending relative to assets & $0.0006 \%$ & $0.0025 \%$ & $0.0067 \%$ & $0.0149 \%$ & $0.1151 \%$ & $0 \%$ \\
\hline Lobby spending relative to sales & $0.0023 \%$ & $0.0049 \%$ & $0.0160 \%$ & $0.1305 \%$ & $0.3712 \%$ & $0 \%$ \\
\hline $\begin{array}{l}\text { Lobby spending relative to market } \\
\text { value }\end{array}$ & $0.0021 \%$ & $0.0052 \%$ & $0.0111 \%$ & $0.0223 \%$ & $0.1021 \%$ & $0 \%$ \\
\hline Book-to-market & 0.5405 & 0.5363 & 0.5288 & 0.5020 & 0.4849 & 0.7120 \\
\hline Sales-to-market & 1.2345 & 1.4492 & 1.3465 & 1.2013 & 1.3486 & 1.9370 \\
\hline Earnings-to-price & -0.0070 & 0.0001 & 0.0076 & 0.0111 & -0.0767 & -0.0796 \\
\hline Dividend yield & 0.0200 & 0.0171 & 0.0177 & 0.0171 & 0.0083 & 0.0161 \\
\hline Return on equity & 0.0984 & 0.0957 & 0.2068 & 0.1316 & 0.0988 & 0.0868 \\
\hline Log Assets & 9.3298 & 8.5327 & 8.2146 & 7.9626 & 6.0142 & 5.5051 \\
\hline
\end{tabular}

The sample includes all stocks on the NYSE, AMEX, and Nasdaq with coverage on the CRSP and Compustat files. In Panel A, each portfolio's average annual buy-and-hold return is reported over the three years prior to portfolio formation; over each year from one to three years after portfolio formation; and averaged over the three years after portfolio formation. Panel B reports each portfolio's average return in excess of the equally weighted return on a control portfolio of stocks matched by firm size and book-tomarket in the first through third years. Panel $\mathrm{C}$ reports characteristics of the portfolios: the average number of component stocks; the ratios of lobbying expenditures to assets, to sales, and to market value of equity; book value of equity relative to market value of equity; sales relative to market value of equity; earnings relative to price; annual dividends divided by market value of equity; return on equity (earnings divided by the prior year's book value of equity); and the natural logarithm of total assets in millions of dollars. 


\section{Table VIII Returns and Characteristics of Portfolios Classified by Lobbying Expenditure Relative to Market Value}

\begin{tabular}{|c|c|c|c|c|c|c|}
\hline Rank & $1($ Low $)$ & 2 & 3 & 4 & 5(High) & $\begin{array}{r}\text { Non- } \\
\text { Lobbying } \\
\end{array}$ \\
\hline \multicolumn{7}{|c|}{ Panel A: Returns before and after portfolio formation } \\
\hline $\begin{array}{l}\text { Average annual return over } 3 \text {-year } \\
\text { period before portfolio formation }\end{array}$ & 0.2578 & 0.2490 & 0.1815 & 0.1712 & 0.1391 & 0.2254 \\
\hline First year after portfolio formation & 0.0800 & 0.1255 & 0.1614 & 0.2249 & 0.3590 & 0.2970 \\
\hline $\begin{array}{l}\text { Second year after portfolio } \\
\text { formation }\end{array}$ & 0.1414 & 0.1594 & 0.1808 & 0.2150 & 0.3026 & 0.2480 \\
\hline Third year after portfolio formation & 0.1148 & 0.1479 & 0.1633 & 0.1981 & 0.2844 & 0.2419 \\
\hline $\begin{array}{l}\text { Average annual return over } 3 \text {-year } \\
\text { period after portfolio formation }\end{array}$ & 0.1120 & 0.1443 & 0.1685 & 0.2127 & 0.3153 & 0.2623 \\
\hline \multicolumn{7}{|c|}{ Panel B: Excess returns before and after portfolio formation } \\
\hline $\begin{array}{l}\text { Average annual return over 3-year } \\
\text { period before portfolio formation }\end{array}$ & -0.0199 & -0.0191 & -0.0723 & -0.0558 & -0.0643 & 0.0060 \\
\hline $\begin{array}{l}\text { First year after portfolio formation } \\
\text { Second year after portfolio }\end{array}$ & -0.0307 & -0.0016 & 0.0268 & 0.0533 & 0.0870 & -0.0035 \\
\hline formation & 0.0087 & 0.0082 & 0.0063 & 0.0187 & 0.0534 & -0.0025 \\
\hline Third year after portfolio formation & -0.0262 & -0.0094 & 0.0013 & 0.0153 & 0.0617 & -0.0011 \\
\hline $\begin{array}{l}\text { Average annual return over } 3 \text {-year } \\
\text { period after portfolio formation }\end{array}$ & -0.0161 & -0.0009 & 0.0114 & 0.0291 & 0.0674 & -0.0024 \\
\hline \multicolumn{7}{|c|}{ Panel C: Characteristics of Portfolios } \\
\hline Average number of observations & 485 & 491 & 490 & 491 & 488 & 18,834 \\
\hline Lobby spending relative to assets & $0.0016 \%$ & $0.0051 \%$ & $0.0097 \%$ & $0.0197 \%$ & $0.1035 \%$ & $0 \%$ \\
\hline Lobby spending relative to sales & $0.0037 \%$ & $0.0139 \%$ & $0.0635 \%$ & $0.0804 \%$ & $0.3613 \%$ & $0 \%$ \\
\hline $\begin{array}{l}\text { Lobby spending relative to market } \\
\text { value }\end{array}$ & $0.0008 \%$ & $0.0030 \%$ & $0.0072 \%$ & $0.0175 \%$ & $0.1144 \%$ & $0 \%$ \\
\hline Book-to-market & 0.3561 & 0.4007 & 0.4683 & 0.5867 & 0.7801 & 0.7120 \\
\hline Sales-to-market & 0.7443 & 0.9177 & 1.1169 & 1.5498 & 2.2504 & 1.9370 \\
\hline Earnings-to-price & 0.0280 & -0.0026 & 0.0120 & -0.0098 & -0.0922 & -0.0796 \\
\hline Dividend yield & 0.0146 & 0.0137 & 0.0167 & 0.0176 & 0.0174 & 0.0161 \\
\hline Return on equity & 0.1977 & 0.0978 & 0.1400 & 0.0588 & 0.1385 & 0.0868 \\
\hline Log Assets & 9.6101 & 8.9058 & 8.2617 & 7.5269 & 5.7513 & 5.5051 \\
\hline
\end{tabular}

The sample includes all stocks on the NYSE, AMEX, and Nasdaq with coverage on the CRSP and Compustat files. In Panel A, each portfolio's average annual buy-and-hold return is reported over the three years prior to portfolio formation; over each year from one to three years after portfolio formation; and averaged over the three years after portfolio formation. Panel B reports each portfolio's average return in excess of the equally weighted return on a control portfolio of stocks matched by firm size and book-tomarket in the first through third years. Panel $\mathrm{C}$ reports characteristics of the portfolios: the average number of component stocks; the ratios of lobbying expenditures to assets, to sales, and to market value of equity; book value of equity relative to market value of equity; sales relative to market value of equity; earnings relative to price; annual dividends divided by market value of equity; return on equity (earnings divided by the prior year's book value of equity); and the natural logarithm of total assets in millions of dollars. 


\section{Table IX Excess Returns of Portfolios Classified by Lobbying Expenditure Relative to Assets and by Past 3-year Return}

\begin{tabular}{|c|c|c|c|c|c|}
\hline \multicolumn{2}{|l|}{ Ranked by } & \multicolumn{3}{|c|}{$\begin{array}{l}\text { Excess Return in Year } \\
\text { after Portfolio Formation }\end{array}$} & \multirow{2}{*}{$\begin{array}{c}\text { Average Excess Return } \\
\text { over } 3 \text { Post-formation } \\
\text { Years }\end{array}$} \\
\hline $\begin{array}{l}\text { Lobby spending } \\
\text { relative to } \\
\text { assets }\end{array}$ & $\begin{array}{l}\text { Past 3-year } \\
\text { return }\end{array}$ & $\begin{array}{l}\text { First } \\
\text { Year }\end{array}$ & $\begin{array}{l}\text { Second } \\
\text { Year }\end{array}$ & $\begin{array}{l}\text { Third } \\
\text { Year }\end{array}$ & \\
\hline \multirow[t]{2}{*}{1 (Low) } & 1 (Low) & -0.0260 & -0.0037 & -0.0141 & -0.0146 \\
\hline & 2(High) & -0.0265 & 0.0435 & -0.0142 & 0.0009 \\
\hline \multirow[t]{2}{*}{2} & 1 & 0.0063 & 0.0393 & 0.0276 & 0.0244 \\
\hline & 2 & 0.0257 & -0.0632 & 0.0154 & -0.0074 \\
\hline \multirow[t]{2}{*}{3} & 1 & -0.0100 & 0.0804 & 0.0002 & 0.0235 \\
\hline & 2 & -0.0124 & 0.0482 & -0.0064 & 0.0098 \\
\hline \multirow[t]{2}{*}{4} & 1 & 0.0118 & 0.0004 & -0.0086 & 0.0012 \\
\hline & 2 & 0.0840 & 0.0003 & 0.0155 & 0.0333 \\
\hline \multirow[t]{2}{*}{ 5(High) } & 1(Low) & 0.1155 & -0.0081 & 0.0116 & 0.0397 \\
\hline & 2(High) & 0.1012 & 0.0539 & 0.0581 & 0.0710 \\
\hline
\end{tabular}

The sample includes all firms listed on NYSE, AMEX, and Nasdaq with coverage on the CRSP and Compustat files. All stocks with lobbying expenditures are ranked by lobbying expenditures relative to assets, and assigned to one of five equally sized portfolios. Within each of the five portfolios, stocks are further ranked by their rates of return over the prior three years and subdivided into two equally sized groups. The table reports each portfolio's average excess return over each of the first three years following portfolio formation and over all three years after portfolio formation. Excess returns are computed relative to a control portfolio of stocks based on size and book-to-market and then past three-year return. The excess return is the difference between the stock's annual buy-and-hold return and the return on the control portfolio. 
Table $X$ Lobbying and Financial Performance

\begin{tabular}{|c|c|c|c|c|c|c|}
\hline \multirow[b]{2}{*}{ Variables } & \multicolumn{2}{|c|}{ 3-month window } & \multicolumn{2}{|c|}{ 2-month window } & \multicolumn{2}{|c|}{ 1-month window } \\
\hline & coefficient & t-stat & coefficient & t-stat & coefficient & t-stat \\
\hline \multicolumn{7}{|c|}{ Panel A: 1-day subsequent to the announcememt date (Jan. 22, 2010) } \\
\hline Intercept & -0.0567 & $-107.35 * * *$ & -0.0531 & $-81.49 * * *$ & -0.0503 & $-56.58 * * *$ \\
\hline Lobby & 0.0573 & $27.15 * * *$ & 0.0541 & $20.78 * * *$ & 0.0503 & $14.15 * * *$ \\
\hline Lobby*Post Citizens United & -0.0040 & -0.24 & -0.0009 & -0.05 & 0.0030 & 0.18 \\
\hline Post Citizens United & 0.0071 & $1.66 *$ & 0.0035 & 0.82 & 0.0007 & 0.17 \\
\hline $\mathrm{n}$ & 426,225 & & 275,583 & & 144,259 & \\
\hline $\mathrm{R}^{2}$ & 0.0017 & & 0.0016 & & 0.0014 & \\
\hline \multicolumn{7}{|c|}{ Panel B: 1-week subsequent to the announcememt date (Jan. 22, 2010) } \\
\hline Intercept & -0.0567 & $-107.53 * * *$ & -0.0531 & $-81.58 * * *$ & -0.0503 & $-56.44 * * *$ \\
\hline Lobby & 0.0573 & $27.19 * * *$ & 0.0541 & $20.8 * * *$ & 0.0503 & $14.11 * * *$ \\
\hline Lobby*Post Citizens United & -0.0013 & -0.18 & 0.0019 & 0.26 & 0.0057 & 0.75 \\
\hline Post Citizens United & -0.0005 & -0.27 & -0.0041 & $-2.25 * *$ & -0.0069 & $-3.63 * * *$ \\
\hline $\mathrm{n}$ & 459,041 & & 308,399 & & 177,075 & \\
\hline $\mathrm{R}^{2}$ & 0.0017 & & 0.0016 & & 0.0016 & \\
\hline \multicolumn{7}{|c|}{ Panel C: 1-day subsequent to the announcememt date (Jan. 22, 2010) } \\
\hline Intercept & -0.0567 & $-107.37 * * *$ & -0.0531 & $-81.5 * * *$ & -0.0503 & $-56.58 * * *$ \\
\hline Lobby & 0.0574 & $27.2 * * *$ & 0.0542 & $20.8 * * *$ & 0.0503 & $14.14 * * *$ \\
\hline Lobby*Post Citizens United & -0.0035 & -0.2 & -0.0003 & -0.02 & 0.0036 & 0.22 \\
\hline Post Citizens United & 0.0071 & $1.66 *$ & 0.0034 & 0.81 & 0.0007 & 0.16 \\
\hline $\mathrm{n}$ & 426,225 & & 275,583 & & 144,259 & \\
\hline $\mathrm{R}^{2}$ & 0.0018 & & 0.0016 & & 0.0014 & \\
\hline \multicolumn{7}{|c|}{ Panel D: 1-week subsequent to the announcememt date (Jan. 22, 2010) } \\
\hline Intercept & -0.0567 & $-107.54 * * *$ & -0.0531 & $-81.58 * * *$ & -0.0503 & $-56.44 * * *$ \\
\hline Lobby & 0.0574 & $27.24 * * *$ & 0.0542 & $20.82 * * *$ & 0.0503 & $14.11 * * *$ \\
\hline Lobby*Post Citizens United & -0.0009 & -0.13 & 0.0023 & 0.31 & 0.0062 & 0.81 \\
\hline Post Citizens United & -0.0005 & -0.28 & -0.0041 & $-2.26 * *$ & -0.0069 & $-3.64 * * *$ \\
\hline $\mathrm{n}$ & 459,041 & & 308,399 & & 177,075 & \\
\hline $\mathrm{R}^{2}$ & 0.0018 & & 0.0016 & & 0.0016 & \\
\hline
\end{tabular}

This table reports OLS estimates of the relationship between stock market returns (the dependent variable) of firms that lobby relative to those with zero lobbying expenditures, pre- and post-Citizens United Supreme Court decision on January 21, 2010, using daily stock return data from the CRSP data base. "Lobby" is a dummy variable which takes the value 1 if the firm lobbied, and 0 if it did not. In Panel A and Panel B, the lobbying sample consists of firms with positive lobbying expenditures in 2009; in Panel C and Panel D, the lobbying sample consists of firms lobbying in three of the five years prior to 2010. Post Citizens United is a dummy variable which takes the value 1 on January 22, 2010 and beyond, and the value 0 for days prior to January 21, 2010. Statistical significance is indicated as follows: $* * * \mathrm{p}<0.01,{ }^{*} \mathrm{p}<0.05,{ }^{*} \mathrm{p}<0.1$ 
Appendix Table 1 Lobbying and Financial Performance

\begin{tabular}{|c|c|c|c|c|c|c|c|c|c|}
\hline VARIABLES & $\begin{array}{l}\text { (1) } \\
\text { ibei }\end{array}$ & $\begin{array}{l}(2) \\
\text { ibei }\end{array}$ & $\begin{array}{l}\text { (3) } \\
\text { ibei }\end{array}$ & $\begin{array}{l}\text { (4) } \\
\text { ni }\end{array}$ & $\begin{array}{l}(5) \\
\text { ni }\end{array}$ & $\begin{array}{l}\text { (6) } \\
\text { ni }\end{array}$ & $\begin{array}{l}\text { (7) } \\
\text { cfo }\end{array}$ & $\begin{array}{l}(8) \\
\text { cfo }\end{array}$ & $\begin{array}{l}\text { (9) } \\
\text { cfo }\end{array}$ \\
\hline $\operatorname{lobby}_{\mathrm{t}-1}$ & $\begin{array}{c}85.405 * * * \\
(3.915)\end{array}$ & $\begin{array}{c}72.505 * * * \\
(4.052)\end{array}$ & $\begin{array}{c}77.084 * * * \\
(3.498)\end{array}$ & $\begin{array}{c}58.006 * * * \\
(2.694)\end{array}$ & $\begin{array}{c}69.043 * * * \\
(3.898)\end{array}$ & $\begin{array}{c}69.206 * * * \\
(3.414)\end{array}$ & $\begin{array}{l}48.859 \\
(1.607)\end{array}$ & $\begin{array}{c}50.018 * * \\
(2.042)\end{array}$ & $\begin{array}{l}36.335 \\
(1.251)\end{array}$ \\
\hline assets & $\begin{array}{c}0.006^{* * *} \\
(4.856)\end{array}$ & $\begin{array}{c}0.006^{* * *} \\
(3.969)\end{array}$ & $\begin{array}{c}0.010 * * * \\
(8.930)\end{array}$ & $\begin{array}{c}0.008 * * * \\
(7.107)\end{array}$ & $\begin{array}{c}0.007 * * * \\
(6.425)\end{array}$ & $\begin{array}{c}0.010 * * * \\
(5.421)\end{array}$ & $\begin{array}{c}0.019 * * * \\
(4.431)\end{array}$ & $\begin{array}{c}0.016^{* * *} \\
(3.931)\end{array}$ & $\begin{array}{c}0.015 * * * \\
(2.745)\end{array}$ \\
\hline market-to-book ratio & $\begin{array}{c}-0.000 \\
(-0.598)\end{array}$ & $\begin{array}{c}0.000 \\
(0.129)\end{array}$ & $\begin{array}{c}-0.001 \\
(-0.694)\end{array}$ & $\begin{array}{c}-0.001 \\
(-0.936)\end{array}$ & $\begin{array}{c}-0.002 \\
(-0.794)\end{array}$ & $\begin{array}{c}-0.003 \\
(-1.031)\end{array}$ & $\begin{array}{c}0.000 \\
(0.007)\end{array}$ & $\begin{array}{c}-0.000 \\
(-0.092)\end{array}$ & $\begin{array}{c}-0.001 \\
(-1.354)\end{array}$ \\
\hline dependent $_{\text {variable }}$ t-1 & & $\begin{array}{c}0.273 * * * \\
(9.938)\end{array}$ & $\begin{array}{c}0.257 * * * \\
(8.395)\end{array}$ & & $\begin{array}{c}0.229 * * * \\
(8.827)\end{array}$ & $\begin{array}{c}0.191 * * * \\
(6.322)\end{array}$ & & $\begin{array}{l}0.304 * * * \\
(10.238)\end{array}$ & $\begin{array}{c}0.278 * * * \\
(8.273)\end{array}$ \\
\hline dependent $_{\text {variable }}$ t-2 & & & $\begin{array}{c}-0.096 * * * \\
(-2.691)\end{array}$ & & & $\begin{array}{c}-0.042 \\
(-1.497)\end{array}$ & & & $\begin{array}{c}0.029 \\
(0.937)\end{array}$ \\
\hline Observations & 35776 & 34822 & 28814 & 34986 & 33809 & 27754 & 30442 & 29497 & 24286 \\
\hline $\begin{array}{l}\text { No. of firms } \\
\text { R-squared (within) }\end{array}$ & $\begin{array}{l}6806 \\
0.084\end{array}$ & $\begin{array}{l}6773 \\
0.155\end{array}$ & $\begin{array}{l}6425 \\
0.173\end{array}$ & $\begin{array}{c}6758 \\
0.0831\end{array}$ & $\begin{array}{c}6697 \\
0.140\end{array}$ & $\begin{array}{c}6311 \\
0.149\end{array}$ & $\begin{array}{c}5957 \\
0.0991\end{array}$ & $\begin{array}{l}5876 \\
0.186\end{array}$ & $\begin{array}{l}5533 \\
0.157\end{array}$ \\
\hline R-squared (between) & 0.315 & 0.547 & 0.423 & 0.224 & 0.456 & 0.433 & 0.201 & 0.584 & 0.709 \\
\hline R-squared (overall) & 0.277 & 0.531 & 0.443 & 0.221 & 0.467 & 0.418 & 0.248 & 0.626 & 0.700 \\
\hline
\end{tabular}

This table reports OLS estimates of the relationship between lobbying and firm performance. The sample excludes firms in Banking and Finance. Firm performance is measured by: $\mathrm{IBEI}=$ income before extraordinary items in year $\mathrm{t} ; \mathrm{NI}=$ net income in year $\mathrm{t}$; $\mathrm{CFO}=\mathrm{cash}$ from operations in year $\mathrm{t}$. Independent variables are: $\mathrm{LOBBY}=$ lobbying spending in year $\mathrm{t}-1$; $\mathrm{MB}=$ market-to-book ratio at the end of year $\mathrm{t}$; ASSET $=$ total assets at the beginning of the year $t$. The sample includes all stocks on the NYSE, AMEX, and Nasdaq with coverage on the CRSP and COMPUSTAT files annually, for the years 1998-2005. All regressions include firm-level fixed effects, Fama-French industry, and time dummies. Two-tailed t-statistics (adjusted for clustering at the firm level) in the parenthesis under the coefficient estimates. *, $* *$, and $* * *$ indicate the regression coefficients are significantly different from zero at the $10 \%, 5 \%$, and $1 \%$ level, respectively. 
Appendix Table 2: Reverse Regressions

\begin{tabular}{|c|c|c|c|}
\hline VARIABLES & $\begin{array}{c}(1) \\
\text { lobby }\end{array}$ & $\begin{array}{c}(2) \\
\text { lobby }\end{array}$ & $\begin{array}{c}(3) \\
\text { lobby }\end{array}$ \\
\hline assets & $\begin{array}{c}0.001 * \\
(1.860)\end{array}$ & $\begin{array}{c}0.001 * * \\
(1.983)\end{array}$ & $\begin{array}{c}0.003 \\
(1.442)\end{array}$ \\
\hline market-to-book ratio & $\begin{array}{c}0.001 \\
(0.729)\end{array}$ & $\begin{array}{c}0.002 \\
(0.804)\end{array}$ & $\begin{array}{c}0.001 \\
(0.316)\end{array}$ \\
\hline $\mathrm{IBEI}_{\mathrm{t}-1}$ & $\begin{array}{c}0.016 \\
(0.962)\end{array}$ & & \\
\hline $\mathrm{NI}_{\mathrm{t}-1}$ & & $\begin{array}{c}-0.016 \\
(-0.987)\end{array}$ & \\
\hline $\mathrm{CFO}_{\mathrm{t}-1}$ & & & $\begin{array}{c}0.002 \\
(1.041)\end{array}$ \\
\hline Observations & 36161 & 35432 & 30993 \\
\hline No. of firms & 6976 & 6943 & 6133 \\
\hline R-squared (within) & 0.203 & 0.288 & 0.275 \\
\hline R-squared (between) & 0.113 & 0.147 & 0.0520 \\
\hline R-squared (overall) & 0.114 & 0.108 & 0.0448 \\
\hline
\end{tabular}

This table reports OLS estimates of the "reverse" regressions: i.e., between lobbying and lagged firm performance. Dependent variable is lobbying spending in year $t$. Independent variables are: $\mathrm{IBEI}=$ income before extraordinary items in year $\mathrm{t}-1$; $\mathrm{NI}=$ net income in year $\mathrm{t}-1 ; \mathrm{CFO}=$ cash from operations in year $\mathrm{t}-1$; Market-to-book ratio $=$ market-to-book ratio at the end of year t; ASSETS = total assets at the beginning of the year $t$. The sample includes all stocks on the NYSE, AMEX, and Nasdaq with coverage on the CRSP and COMPUSTAT files annually, for the years 1998-2005. All regressions include Fama-French industry dummies and time dummies. Two-tailed t-statistics (adjusted for clustering at the firm level) in the parenthesis under the coefficient estimates. $* * *$, and $* * *$ indicate the regression coefficients are significantly different from zero at the $10 \%, 5 \%$, and $1 \%$ level, respectively. All coefficients have been multiplied by 1000 . 
Appendix Table 3 Lobbying and Financial Performance: Contemporaneous Lobbying

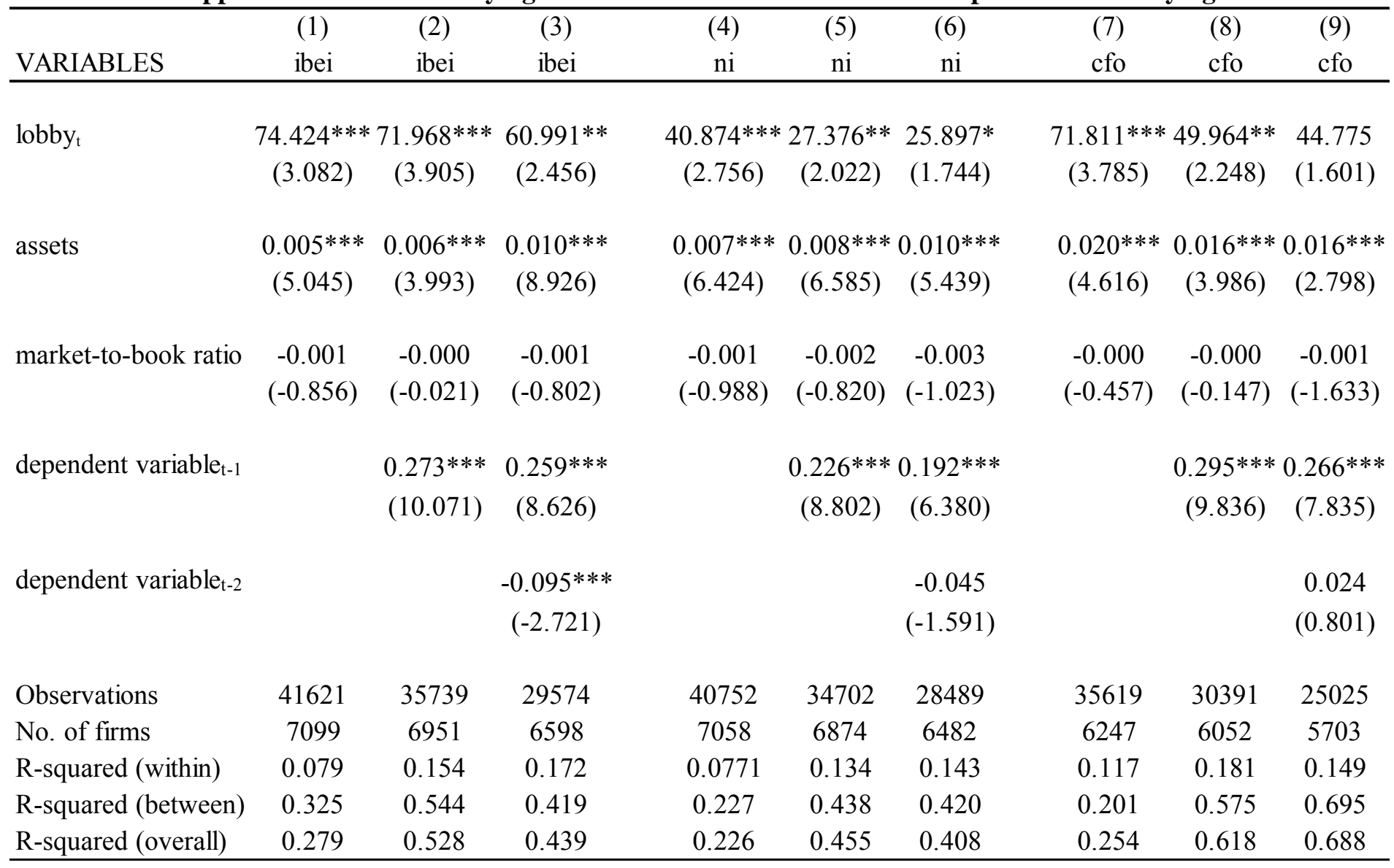

This table reports OLS estimates of the relationship between lobbying and firm performance. Firm performance is measured by: IBEI $=$ income before extraordinary items in year $t$; $\mathrm{NI}=$ net income in year $\mathrm{t}$; $\mathrm{CFO}=$ cash from operations in year $\mathrm{t}$. Independent variables are: LOBBY = lobbying spending in year $\mathrm{t}$; MB $=$ market-to-book ratio at the end of year $\mathrm{t}$; ASSET = total assets at the beginning of the year $t$. The sample includes all stocks on the NYSE, AMEX, and Nasdaq with coverage on the CRSP and COMPUSTAT files annually, for the years 1998-2005. All regressions include firm-level fixed effects, Fama-French industry, and time dummies. Two-tailed t-statistics (adjusted for clustering at the firm level) in the parenthesis under the coefficient estimates. ${ }^{*}, * *$, and $* * *$ indicate the regression coefficients are significantly different from zero at the $10 \%, 5 \%$, and $1 \%$ level, respectively. 
Appendix Table 4 Lobbying and Financial Performance: (Current and One period Lag of Lobbying)

\begin{tabular}{|c|c|c|c|c|c|c|c|c|c|}
\hline & (1) & $(2)$ & (3) & (4) & (5) & (6) & (7) & (8) & (9) \\
\hline VARIABLES & ibei & ibei & ibei & ni & ni & ni & cfo & cfo & cfo \\
\hline$\Sigma$ lobby $(\mathrm{t}, \mathrm{t}-1)$ & $\begin{array}{c}134.43 * * * \\
(4.593)\end{array}$ & $\begin{array}{c}104.1 * * * \\
(4.157)\end{array}$ & $\begin{array}{c}91.57 * * * \\
(3.690)\end{array}$ & $\begin{array}{c}67.07 * * * \\
(3.223)\end{array}$ & $\begin{array}{c}65.65 * * * \\
(3.920)\end{array}$ & $\begin{array}{c}67.51 * * * \\
(3.252)\end{array}$ & $\begin{array}{c}83.02 * * * \\
(2.704)\end{array}$ & $\begin{array}{l}69.45 * * \\
(2.364)\end{array}$ & $\begin{array}{c}58.91 \\
(1.601)\end{array}$ \\
\hline assets & $\begin{array}{c}0.006^{* * *} \\
(4.848)\end{array}$ & $\begin{array}{c}0.006 * * * \\
(3.969)\end{array}$ & $\begin{array}{c}0.010 * * * \\
(8.926)\end{array}$ & $\begin{array}{c}0.008 * * * \\
(7.148)\end{array}$ & $\begin{array}{c}0.007 * * * \\
(6.547)\end{array}$ & $\begin{array}{c}0.010 * * * \\
(5.452)\end{array}$ & $\begin{array}{c}0.019 * * * \\
(4.487)\end{array}$ & $\begin{array}{c}0.016 * * * \\
(3.973)\end{array}$ & $\begin{array}{c}0.016 * * * \\
(2.798)\end{array}$ \\
\hline market-to-book ratio & $\begin{array}{c}-0.001 \\
(-0.850)\end{array}$ & $\begin{array}{c}0.000 \\
(0.009)\end{array}$ & $\begin{array}{c}-0.001 \\
(-0.753)\end{array}$ & $\begin{array}{c}-0.001 \\
(-0.991)\end{array}$ & $\begin{array}{c}-0.002 \\
(-0.823)\end{array}$ & $\begin{array}{c}-0.003 \\
(-1.035)\end{array}$ & $\begin{array}{c}-0.000 \\
(-0.166)\end{array}$ & $\begin{array}{c}-0.000 \\
(-0.103)\end{array}$ & $\begin{array}{c}-0.001 \\
(-1.508)\end{array}$ \\
\hline dependent variable $_{t-1}$ & & $\begin{array}{c}0.270 * * * \\
(9.994)\end{array}$ & $\begin{array}{c}0.257 * * * \\
(8.552)\end{array}$ & & $\begin{array}{c}0.224 * * * \\
(8.697)\end{array}$ & $\begin{array}{c}0.188 * * * \\
(6.265)\end{array}$ & & $\begin{array}{c}0.294 * * * \\
(9.839)\end{array}$ & $\begin{array}{c}0.265 * * * \\
(7.851)\end{array}$ \\
\hline dependent variable $_{t-2}$ & & & $\begin{array}{c}-0.094 * * * \\
(-2.698)\end{array}$ & & & $\begin{array}{c}-0.043 \\
(-1.561)\end{array}$ & & & $\begin{array}{c}0.023 \\
(0.768)\end{array}$ \\
\hline Observations & 36706 & 35739 & 29574 & 35899 & 34702 & 28489 & 31355 & 30391 & 25025 \\
\hline No. of firms & 6986 & 6951 & 6598 & 6938 & 6874 & 6482 & 6136 & 6052 & 5703 \\
\hline R-squared (within) & 0.0892 & 0.156 & 0.175 & 0.0835 & 0.138 & 0.147 & 0.101 & 0.181 & 0.150 \\
\hline R-squared (between) & 0.332 & 0.552 & 0.427 & 0.226 & 0.450 & 0.429 & 0.207 & 0.577 & 0.696 \\
\hline R-squared (overall) & 0.292 & 0.534 & 0.447 & 0.224 & 0.463 & 0.415 & 0.256 & 0.619 & 0.687 \\
\hline
\end{tabular}

This table reports OLS estimates of the relationship between lobbying and firm performance. Firm performance is measured by: $\mathrm{IBEI}=$ income before extraordinary items in year $\mathrm{t} ; \mathrm{NI}=$ net income in year $\mathrm{t} ; \mathrm{CFO}=$ cash from operations in year $\mathrm{t}$. Independent variables are: $\mathrm{LOBBY}=$ lobbying spending in years $\mathrm{t}$ and $\mathrm{t}-1 ; \mathrm{MB}=$ market-to-book ratio at the end of year $\mathrm{t}$; ASSET $=$ total assets at the beginning of the year t. The sample includes all stocks on the NYSE, AMEX, and Nasdaq with coverage on the CRSP and COMPUSTAT files annually, for the years 1998-2005. All regressions include firm-level fixed effects, Fama-French industry, and time dummies. Two-tailed t-statistics (adjusted for clustering at the firm level) in the parenthesis under the coefficient estimates. *, **, and $* * *$ indicate the regression coefficients are significantly different from zero at the $10 \%, 5 \%$, and $1 \%$ level, respectively.

$* * * \mathrm{p}<0.01, * * \mathrm{p}<0.05, * \mathrm{p}<0.1$ 
Appendix Table 5 Lobbying and Financial Performance: (Current and Two Lags of Lobbying)

\begin{tabular}{|c|c|c|c|c|c|c|c|c|c|}
\hline & (1) & (2) & (3) & (4) & (5) & (6) & (7) & (8) & (9) \\
\hline VARIABLES & ibei & ibei & ibei & ni & ni & ni & cfo & cfo & cfo \\
\hline$\Sigma$ lobby $(\mathrm{t}, \mathrm{t}-1, \mathrm{t}-2)$ & $\begin{array}{c}176.28 * * * \\
(4.007)\end{array}$ & $\begin{array}{c}154.4 * * * \\
(4.110)\end{array}$ & $\begin{array}{c}141.2 * * * \\
(4.025)\end{array}$ & $\begin{array}{c}108.7 * * * \\
(3.515)\end{array}$ & $\begin{array}{c}107.8 * * * \\
(3.584)\end{array}$ & $\begin{array}{c}108.8 * * * \\
(3.971)\end{array}$ & $\begin{array}{l}83.02 * \\
(1.853)\end{array}$ & $\begin{array}{c}69.45 \\
(1.341)\end{array}$ & $\begin{array}{c}58.91 \\
(1.256)\end{array}$ \\
\hline assets & $\begin{array}{c}0.006 * * * \\
(4.936)\end{array}$ & $\begin{array}{c}0.007 * * * \\
(4.421)\end{array}$ & $\begin{array}{c}0.009 * * * \\
(8.875)\end{array}$ & $\begin{array}{c}0.008 * * * \\
(6.492)\end{array}$ & $\begin{array}{c}0.008 * * * \\
(6.034)\end{array}$ & $\begin{array}{c}0.010 * * * \\
(5.468)\end{array}$ & $\begin{array}{c}0.017 * * * \\
(3.229)\end{array}$ & $\begin{array}{c}0.015 * * * \\
(2.983)\end{array}$ & $\begin{array}{c}0.016 * * * \\
(2.799)\end{array}$ \\
\hline market-to-book ratio & $\begin{array}{c}-0.001 \\
(-0.608)\end{array}$ & $\begin{array}{c}-0.001 \\
(-0.544)\end{array}$ & $\begin{array}{c}-0.001 \\
(-0.819)\end{array}$ & $\begin{array}{c}-0.002 \\
(-0.880)\end{array}$ & $\begin{array}{c}-0.003 \\
(-0.939)\end{array}$ & $\begin{array}{c}-0.003 \\
(-1.044)\end{array}$ & $\begin{array}{c}-0.001 \\
(-1.113)\end{array}$ & $\begin{array}{c}-0.001 \\
(-1.314)\end{array}$ & $\begin{array}{c}-0.001 \\
(-1.510)\end{array}$ \\
\hline dependent $_{\text {variable }}$ t-1 & & $\begin{array}{c}0.225 * * * \\
(8.088)\end{array}$ & $\begin{array}{c}0.254 * * * \\
(8.467)\end{array}$ & & $\begin{array}{c}0.179 * * * \\
(6.463)\end{array}$ & $\begin{array}{c}0.183 * * * \\
(6.138)\end{array}$ & & $\begin{array}{c}0.254 * * * \\
(7.763)\end{array}$ & $\begin{array}{c}0.265 * * * \\
(7.853)\end{array}$ \\
\hline dependent $_{\text {variable }}$ t-2 & & & $\begin{array}{c}-0.096 * * * \\
(-2.774)\end{array}$ & & & $\begin{array}{c}-0.045 \\
(-1.605)\end{array}$ & & & $\begin{array}{c}0.023 \\
(0.761)\end{array}$ \\
\hline Observations & 31094 & 30532 & 29574 & 30370 & 29596 & 28489 & 26502 & 25900 & 25025 \\
\hline No. of firms & 6758 & 6720 & 6598 & 6700 & 6626 & 6482 & 5905 & 5828 & 5703 \\
\hline R-squared (within) & 0.0959 & 0.149 & 0.178 & 0.0906 & 0.134 & 0.150 & 0.0749 & 0.135 & 0.150 \\
\hline R-squared (between) & 0.322 & 0.483 & 0.438 & 0.231 & 0.384 & 0.434 & 0.232 & 0.568 & 0.696 \\
\hline R-squared (overall) & 0.288 & 0.481 & 0.455 & 0.219 & 0.409 & 0.418 & 0.287 & 0.611 & 0.687 \\
\hline
\end{tabular}

This table reports OLS estimates of the relationship between lobbying and firm performance. Firm performance is measured by: IBEI $=$ income before extraordinary items in year $\mathrm{t} ; \mathrm{NI}=$ net income in year $\mathrm{t} ; \mathrm{CFO}=$ cash from operations in year $\mathrm{t}$. Independent variables are: LOBBY = lobbying spending in years $t, t-1$, and $t-2 ; \mathrm{MB}=$ market-to-book ratio at the end of year $t$; ASSET $=$ total assets at the beginning of the year t. The sample includes all stocks on the NYSE, AMEX, and Nasdaq with coverage on the CRSP and COMPUSTAT files annually, for the years 1998-2005. All regressions include firm-level fixed effects, Fama-French industry, and time dummies. Two-tailed t-statistics (adjusted for clustering at the firm level) in the parenthesis under the coefficient estimates. ${ }^{*}, *$, and $* * *$ indicate the regression coefficients are significantly different from zero at the $10 \%, 5 \%$, and $1 \%$ level, respectively.

$* * * \mathrm{p}<0.01, * * \mathrm{p}<0.05,{ }^{*} \mathrm{p}<0.1$ 
Appendix Table 6 Lobbying and Financial Performance: (Largest Lobbying Spenders)

\begin{tabular}{|c|c|c|c|c|c|c|c|c|c|}
\hline & $(1)$ & $(2)$ & (3) & (4) & (5) & (6) & (7) & (8) & (9) \\
\hline VARIABLES & ibei & ibei & ibei & ni & ni & ni & cfo & cfo & cfo \\
\hline $\operatorname{lobby}_{\mathrm{t}-1}$ & $\begin{array}{c}78.585 * * * \\
(2.868)\end{array}$ & $\begin{array}{c}66.939 * * * \\
(2.890)\end{array}$ & $\begin{array}{c}87.860 * * * \\
(4.036)\end{array}$ & $\begin{array}{l}31.567 \\
(1.159)\end{array}$ & $\begin{array}{c}45.194 * * \\
(2.012)\end{array}$ & $\begin{array}{c}57.404 * * \\
(2.048)\end{array}$ & $\begin{array}{l}39.707 \\
(0.888)\end{array}$ & $\begin{array}{c}94.643 * * \\
(2.466)\end{array}$ & $\begin{array}{l}62.157 \\
(1.363)\end{array}$ \\
\hline assets & $\begin{array}{c}0.005^{* * *} \\
(4.106)\end{array}$ & $\begin{array}{c}0.005 * * * \\
(2.941)\end{array}$ & $\begin{array}{c}0.012 * * * \\
(7.254)\end{array}$ & $\begin{array}{c}0.007 * * * \\
(5.938)\end{array}$ & $\begin{array}{c}0.007 * * * \\
(5.602)\end{array}$ & $\begin{array}{c}0.009 * * * \\
(4.096)\end{array}$ & $\begin{array}{c}0.016 * * * \\
(3.217)\end{array}$ & $\begin{array}{c}0.013 * * * \\
(2.734)\end{array}$ & $\begin{array}{l}0.012 * \\
(1.864)\end{array}$ \\
\hline market-to-book ratio & $\begin{array}{c}-0.000 \\
(-0.425)\end{array}$ & $\begin{array}{c}0.001 \\
(0.474)\end{array}$ & $\begin{array}{c}-0.000 \\
(-0.274)\end{array}$ & $\begin{array}{c}-0.000 \\
(-0.184)\end{array}$ & $\begin{array}{c}0.000 \\
(0.367)\end{array}$ & $\begin{array}{c}-0.000 \\
(-0.089)\end{array}$ & $\begin{array}{c}-0.000 \\
(-0.236)\end{array}$ & $\begin{array}{c}0.000 \\
(0.002)\end{array}$ & $\begin{array}{l}-0.001 * \\
(-1.721)\end{array}$ \\
\hline dependent variable $_{t-1}$ & & $\begin{array}{c}0.219 * * * \\
(6.954)\end{array}$ & $\begin{array}{c}0.185 * * * \\
(5.140)\end{array}$ & & $\begin{array}{c}0.207 * * * \\
(6.417)\end{array}$ & $\begin{array}{c}0.150 * * * \\
(3.915)\end{array}$ & & $\begin{array}{c}0.314 * * * \\
(7.994)\end{array}$ & $\begin{array}{c}0.292 * * * \\
(6.642)\end{array}$ \\
\hline 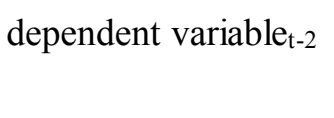 & & & $\begin{array}{c}-0.126 * * * \\
(-2.713)\end{array}$ & & & $\begin{array}{l}-0.062 * \\
(-1.903)\end{array}$ & & & $\begin{array}{c}0.041 \\
(1.134)\end{array}$ \\
\hline Observations & 33034 & 32178 & 26286 & 32431 & 31392 & 25494 & 27970 & 27124 & 22021 \\
\hline No. of firms & 6621 & 6586 & 6169 & 6571 & 6509 & 6056 & 5783 & 5705 & 5282 \\
\hline R-squared (within) & 0.073 & 0.117 & 0.154 & 0.0671 & 0.120 & 0.122 & 0.0820 & 0.168 & 0.146 \\
\hline R-squared (between) & 0.324 & 0.513 & 0.339 & 0.215 & 0.418 & 0.388 & 0.193 & 0.617 & 0.735 \\
\hline R-squared (overall) & 0.281 & 0.493 & 0.360 & 0.208 & 0.438 & 0.372 & 0.215 & 0.635 & 0.725 \\
\hline
\end{tabular}

This table reports OLS estimates of the relationship between lobbying and firm performance; it excludes firms with nonzero lobbying expenditures less than the top quartile. Firm performance is measured by: IBEI = income before extraordinary items in year $\mathrm{t}$; $\mathrm{NI}=$ net income in year $\mathrm{t}$; $\mathrm{CFO}=$ cash from operations in year $\mathrm{t}$. Independent variables are: $\mathrm{LOBBY}=$ lobbying spending in year $\mathrm{t}-1 ; \mathrm{MB}=$ market-to-book ratio at the end of year $\mathrm{t}$; ASSET $=$ total assets at the beginning of the year $\mathrm{t}$. The sample includes all stocks on the NYSE, AMEX, and Nasdaq with coverage on the CRSP and COMPUSTAT files annually, for the years 19982005. All regressions include firm-level fixed effects, Fama-French industry, and time dummies. Two-tailed t-statistics (adjusted for clustering at the firm level) in the parenthesis under the coefficient estimates. ${ }^{*}, *$, and $* * *$ indicate the regression coefficients are significantly different from zero at the $10 \%, 5 \%$, and $1 \%$ level, respectively. 